\title{
Modulation of Stem and Progenitor Cells and Bleomycin-induced Pulmonary Fibrosis by Spiperone in Mice
}

\author{
Skurikhin EG, Pershina OV *, Khmelevskaya ES, Ermakova NN, Reztsova AM, Krupin VA and Dygai AM
}

Department of Pathophysiology and Regenerative Medicine, Federal State Institution "Scientific-Research Institute of Pharmacology" Siberian Branch of the Academy of Medical Sciences, st. Lenin, 3, Tomsk, Russia

\begin{abstract}
Bleomycin-induced lung inflammation and fibrosis were assessed in a model of idiopathic pulmonary fibrosis in C57BL/6 mice and effect of spiperone on histopathological lung indicators, hematopoietic (HSC) and mesenchymal (MSC) stem cells and progenitor cells was characterized. Spiperone is a selective antagonist of $D_{2}$ dopamine receptors which disturbs dopamine mediation. Hematoxylin and eosin staining showed spiperone decreased alveolar epithelial edema, exudation and infiltration of the alveoli walls and lumen by inflammatory cells (neutrophils, macrophages, plasma cells) after bleomycin instillation. Picrofuchsin staining by Van Gieson revealed spiperone decreases the area of connective tissue in the lung fibrotic phase of pulmonary fibrosis. ELISA assay determined the decrease levels of collagen type I, hydroxyproline and total collagen in lung homogenate after spiperone treatment. Number of "long-term" HSCs (Lin- Sca- $\left.1^{+} \mathrm{C}-\mathrm{Kit}^{+} \mathrm{CD} 34\right)$, «short-term" HSCs (Lin-Sca- $1^{+} \mathrm{C}-\mathrm{Kit}^{+} \mathrm{CD} 34^{+}$), hematopoietic progenitor cells and MSC-like cells in lung with pneumofibrosis decreased after spiperone treatment. This spiperone effect we connect to the violation of immature bone marrow cells migration. Additionally, spiperone inhibited clonal activity of hematopoietic (CFU-GEMM, CFU-G) and mesenchymal (CFU-F) progenitor of bone marrow, blood and lungs. An additional feature of the spiperone action was the ability to decrease the capacity of self-renewal and MSCs differentiation activity into adipocytes, osteoblasts, chondrocytes and fibroblast cells. Thus, a selective antagonist $D_{2}$ of dopamine receptors spiperone can act as a potential antifibrotic agent for the treatment of toxic pulmonary fibrosis. The overall conclusion was that the neurotropic agent spiperone is able to influence the stem and progenitor cells in lung pathology effectively.
\end{abstract}

Keywords: Spiperone; Hematopoietic stem cells; Mesenchymal stem cells; Progenitor cells; Pulmonary fibrosis

\section{Introduction}

Idiopathic pulmonary fibrosis is a chronic actively progressive disease of unknown etiology. Prognosis of the disease in the majority is unfavorable, the condition of patients failures rapidly. Life expectancy after diagnosis is from 2 to 4 years [1,2]. The current set of therapeutic interventions for pulmonary fibrosis is limited and not effective. Clinical practice focuses primarily on the treatment of complications and maintenance therapy [3].

The neurotransmitter dopamine has various physiological functions in the central nervous system. Dopamine plays an important role in the mechanisms of movement, cognition and emotion $[4,5]$. The cause of Parkinson's disease, schizophrenia, autism, attention deficit, hyperactivity disorder, and drug abuse are associated with dopamine deficit. Dopamine $\mathrm{D}_{1}$ and $\mathrm{D}_{2}$ receptor subtypes of the central nervous system are characterized pharmacologically and biochemically [6]. It is known that dopamine $\mathrm{D}_{2}$ receptors are involved in the pathophysiology of Parkinson's disease, Alzheimer's disease and schizophrenia [7]. Biodistribution studies in rats showed a high uptake of radioactivity in the lung $(1.80 \%$ injected dose (ID)/g) at $15 \mathrm{~min}$ after injection of $3-\mathrm{N}-\left(2-\left[{ }^{18} \mathrm{~F}\right]\right.$ Fluoroethyl spiperone [8]. Dopamine and dopamine receptors (D1-4 subtypes) are determined in lung tissue [9]. Dopamine $D_{1}$ and $D_{2}$ receptor subtypes are described in lung vessels $[10,11$. We do not exclude that dopamine and dopamine receptors may be involved in the pathophysiology of pulmonary disorders, including the pathophysiology of idiopathic pulmonary fibrosis.

Spiperone is selective $\mathrm{D}_{2}$ dopamine receptor antagonist, $a_{1 \mathrm{~B}}$ adrenoceptor antagonist; mixed $5-\mathrm{HT}_{2 \mathrm{~A}} / 5-\mathrm{HT}_{1}$ serotonin receptor antagonist [12]. The main effect of systemic administration of spiperone is neuroleptic. Meanwhile, subcutaneous, intravenous, intraperitoneal, intramuscular, and per oral administration of spiperone induces immunosuppression [13]. The ability of spiperone to reduce tissue edema and leukocyte infiltration after subcutaneous injection was shown in mice infected with oxazolone. Spiperone and its active derivatives are used as a mean for the treatment of contact dermatitis, atopic dermatitis, psoriasis, Sjogren's syndrome, alopecia areata, aphthous ulcers, conjunctivitis, ulcerative colitis, asthma, scleroderma, vaginitis, proctitis $[13,14]$.

Given the above data, we hypothesized that pulmonary fibrogenesis may be altered by disrupting dopamine mediation by spiperone. In addition, it is possible that in addition to the morphological and biochemical indices of pulmonary fibrosis spiperone can affect mesenchymal stem cells (MSCs) and hematopoietic stem cells (HSCs). We have previously shown that sympatholytic reserpine affects HSCs and hematopoietic progenitor cells, which resulted in a decrease in pulmonary fibrosis [15]. From our perspective, it is necessary to add to the list new compounds that could affect the endogenous stem and progenitor cells. Change in the activity of endogenous stem and progenitor cell by drugs may be a promising approach of diseases treatment.

*Corresponding author: Pershina OV, Department of Pathophysiology and Regenerative Medicine, Federal State Institution "Scientific-Research Institute of Pharmacology" Siberian Branch of the Academy of Medical Sciences, st. Lenin, 3 , Tomsk, Russia 634028, Tel: 73822418375; E-mail: ovpershina@gmail.com

Received April 28, 2014; Accepted May 31, 2014; Published June 02, 2014

Citation: Skurikhin EG, Pershina OV, Khmelevskaya ES, Ermakova NN, Reztsova AM, et al. (2014) Modulation of Stem and Progenitor Cells and Bleomycininduced Pulmonary Fibrosis by Spiperone in Mice. J Stem Cell Res Ther 4: 210 doi:10.4172/2157-7633.1000210

Copyright: (c) 2014 Skurikhin EG, et al. This is an open-access article distributed under the terms of the Creative Commons Attribution License, which permits unrestricted use, distribution, and reproduction in any medium, provided the original author and source are credited. 
The objectives of this study were: 1) to assess whether spiperone decrease the development of bleomycin-induced pulmonary fibrosis in C57BL/6 mice; 2) to study the effect of spiperone on HSCs and MSCs and progenitor cells in pulmonary fibrosis.

These studies demonstrated antifibrotic effect of spiperone in C57BL/6 mice for the first time on the model of bleomycin injury of alveolar epithelium. During fibrosis spiperone reduced the capacity of lung MSCs for self-renewal and their activity to differentiate into stromal cells lines, reduced the number of progenitor fibroblast cells with high clonal activity in bone marrow, lungs and blood. In addition, spiperone inhibited migration of HSCs and hematopoietic progenitor cells from bone marrow into the lungs, inhibited clonal activity of bone marrow and circulating granulocyte-erythroid-macrophagemegakaryocytic and granulocyte precursors.

\section{Materials and Methods}

\section{Animals}

C57BL/6 mice, 10-12 weeks of age, were purchased from the Dept. of Biomodels, Research Institute of Pharmacology, SB of RAMS (Tomsk, Veterinary Certificate Number 270 № 0007293). Mice were housed five animals per cage (VELAZ) under normal laboratory conditions. All experimental procedures with animals were performed in accordance with the European Convention for the Protection of Vertebrate Animals used for Experimental and other Scientific Purposes (March, 18, 1986; Strasburg; ETS 123) and the Order of Public Health Ministry of Russian Federation 267 (Moscow, 2003, June, 19). All animal experiments were approved by the Animal Care Committee of the Research Institute of Pharmacology (№ 01022011). Mice were handled minimally and humanely throughout the study and no signs of hypothermia or irregular grooming were noted. During the study 270 mice were used.

\section{Reagents}

Bleomycin sulphate was purchased from Bristol Myers-Squibb (Blenoxane ${ }^{\circledR}$; São Paulo, Brazil). Spiperone - selective $\mathrm{D}_{2}$ dopamine receptor antagonist, $\alpha_{1 \mathrm{~B}}$-adrenoceptor antagonist; mixed 5- $\mathrm{HT}_{2 \mathrm{~A}} /$ $5-\mathrm{HT}_{1}$ serotonin receptor antagonist (Sigma, USA).

\section{Modelling of alveolar epithelium toxic damage by bleomycin, spiperone administration, groups of animals}

Control animals were administered a single intratracheal $30 \mu \mathrm{l}$ $\mathrm{NaCl} 0.9 \%$. Alveolar epithelial injury in mice C57BL/6 induced by a single intratracheal bleomycin administration at a dose of $80 \mu \mathrm{g} /$ mouse in $30 \mu \mathrm{l} \mathrm{NaCl} 0.9 \%$ [16]. These animals formed the bleomycin control. Spiperone dose of $1.5 \mathrm{mg} / \mathrm{kg}$ in $100 \mathrm{ml} \mathrm{NaCl} 0.9 \%$ was injected intraperitoneally in 3 hours and on the 1st, 3rd, 6th, 7th, 13th, 21st days after bleomycin instillation. Mice with bleomycin damage of alveolar epithelium and treated by spiperone formed the experimental group. $\mathrm{NaCl}$ and bleomycin intratracheal administration was taken for 0 -day of the experiment. Mice were humanely sacrificed by $\mathrm{CO}_{2}$ asphyxiation.

\section{Histopathological studies of lung}

For histological research lung right lobe was fixed in 10\% neutral formalin and embedded into paraffin by standard techniques. Dewaxed 5 micron thick slices were stained by hematoxylin-eosin and azure eosin and 7 microns thick by Van Gieson method [17,18]. At least 10 photomicrographs without overlapping across the cut surface of the lung tissue at $100 \mathrm{x}$ magnification were taken for each experimental animal Used system consists of a microscope (Axio Lab.A1, Carl Zeiss
MicroImaging GmbH; Göttingen, Germany) with a video camera (AxioCam ERc5s, Carl Zeiss; Göttingen, Germany), connected to a personal computer. Gathered images were processed using the software AxioVision Rel.4.8.2.

Also histological section staining by hematoxylin-eosin was used to detect inflammatory cells in the lung tissue.

\section{Stem and progenitor cells experimental design}

1. Samples collection for research (cells of bone marrow, blood and lung).

2. Flow cytometric detection of membrane receptors expression in cells from bone marrow, blood and lung.

3. Suspension separation of just isolated cells into adherent and non-adherent factions.

4. Research of adherent and non-adherent cells clonal activity from bone marrow, blood and lung. Morphological and flow cytometric assessment of colony forming units (CFU) cells.

5. Lung adherent cells potential for self-renewal assessment during long-term cultivation.

6. Expression evaluation of cells membrane receptors obtained during long-term cultivation.

7. Study of MSC-like cells differentiation obtained during longterm cultivation into mature stromal lines cells.

\section{Flow cytometric analysis}

Membrane receptors expression of mesenchymal stem cells in bone marrow and lungs was analyzed using $\mathrm{BD}$ surface markers (BD Biosciences, USA). The mononuclear cells were stained for 30 minutes with the following antibodies: anti-rat CD90 (Thy-1)/ mouse CD90. 1 (PerCP), CD34 FITS, CD45 PE/Cy5, CD73 (PE), CD106 (VCAM-1) FITS, CD44 (Pgp-1, Ly-24) APC and anti-mouse CD31 (PECAM-1) APC (BD Biosciences, USA). Also the following control groups of isotype: FITS Rat IgG2a, PerCP Mouse IgG1, APC Rat IgG2b, APC-Cy7 Rat IgG2b, PE Rat IgG2a were used. The labeled cells were thoroughly washed with PBS $x 2$ and analyzed on FACSCanto II (Becton Dickinson) with the with FACS Diva software program. A minimum of 100,000 events were recorded for each tube.

Membrane receptor's expression of murine HSCs from bone marrow or lung were assayed according to the protocol for BD Mouse Hematopoietic Stem and Progenitor Cell Isolation Kit (BD Biosciences, US). The labeled cells were thoroughly washed with PBS $\times 2$ and analyzed on FACSCanto II (Becton Dickinson) with the with FACS Diva software program. A minimum of 50,000 events were recorded for each tube.

\section{Culture studies}

The expression of CD45 receptor on bone marrow, blood, and lung cells was previously investigated, after that cells suspension was separated into adherent and non-adherent fractions.

Long-term cultures of adherent lung mononuclear cells: Lung mononuclear cells in amount of $0.5-1.0 \times 10^{8}$ were resuspended in 7 $\mathrm{ml}$ of preheated culture medium to $37^{\circ} \mathrm{C}$ consisting of $90 \%$ DMEMLG (Sigma, USA), 10\% inactivated FBS (HyClone, USA), $2 \mathrm{mM}$ L-glutamine (Sigma, USA), antibiotics solution (Sigma, USA). After that the cell suspension was put into the culture bottle with an area of $25 \mathrm{~cm}$ and ventilated cup (TPP AG, Switzerland) and incubated at 
$37^{\circ} \mathrm{C}, 5 \% \mathrm{CO}_{2}$ and $100 \%$ humidity. In $48-72$ hours the supernatant fluid with non-adherent cells was removed, base culture medium was replaced by a new fragment. Next changes of medium were made every 3-4 days until achieving up to $70 \%-90 \%$ coverage of the bottle surface with cells.

After reaching the maximum fusion $(70-90 \%$ of the total bottle surface) the cell culture was washed twice with phosphate buffer (PBS; Sigma USA). The cells removed from the plastic surface using a cell silicone spatula with a free rotation of the cutting edge width of 13 mm (TPP AG, Switzerland). Detached cells were washed out by PBS (Sigma, USA) for later use (the second passage). Mononuclear cells concentration after repeated passaging was $0.5-1.0 \times 10^{7}$ in $7 \mathrm{ml}$ of base culture medium. At the end of the cultivation cycle the cell culture was washed twice with PBS in a culture bottle and removed from the surface by the silicon spatula. The mononuclear cells suspension was transferred into tubes and centrifuged for 5-7 min at $1500 \mathrm{rpm}$. Supernatant was replaced by $1-2 \mathrm{~mL}$ of the base culture medium, counted the number of mononuclear cells and evaluated their immune profile.

Morphological estimation of cell culture condition was carried out at each change of base medium and at maximum cell fusion achievement. Doubling time (tD) of endothelial and epithelial cells, and fibroblast cells was calculated as previously described [19-21].

The study of multilineage differentiation potential of MSC-like lung cells: To confirm the osteogenic differentiation, cells obtained after prolonged cultivation were inoculated into 6-well culture plate $\left(2,5 \times 10^{5}\right.$ cells/well) in medium containing $90 \%$ DMEM-LG ((Sigma, USA), 10\% FBS (HyClone, USA) and supplemented with $0.2 \mathrm{mM}$ 2-phosphate, $\mathrm{L}$-ascorbic acid, $10 \mathrm{mM} \beta$-glycerophosphate, $1 \times 10^{-8}$ $\mathrm{mM}$ dexamethasone, penicillin and streptomycin (all supplements from Sigma, USA)). The medium was changed every 3-4 days. 21 day cultures were washed twice with PBS (Sigma, USA) and fixed in $4 \%$ formaldehyde (Pancreac, USA) for $10 \mathrm{~min}$. Mineralization of the extracellular matrix served as an indicator of osteogenic differentiation. Mineralization was visualized using the von Kossa staining method [21,22].

To study the adipogenic differentiation, MSC-like cells were seeded into 6 -well cultivated plates $\left(2,5 \times 10^{5}\right.$ cells/well $)$ and cultivated in medium containing 90\% DMEM-LG (Sigma, USA), $10 \%$ inactivated FBS (HyClone, USA), penicillin and streptomycin, $0.5 \mathrm{mM}$ hydrocortisone, $60 \mu \mathrm{M}$ indomethacin, $1 \mu \mathrm{g} / \mathrm{mL}$ insulin (all supplements from Sigma, USA). The medium was changed every 4 days. The complete cycle of cultivation was 21 days. The adipogenic differentiation was estimated by staining of intracellular accumulation of lipids $0.5 \%$ red oil O (Sigma, USA) [22-24].

Granular cultures of MSC-like cells for chondrogenesis study were prepared from $4 \times 10^{5}$ cells placed into $15 \mathrm{ml}$ polypropylene tubes (TPP AG, Switzerland) in a medium of the following composition: 95\% DMEM-HG, 2 mM L-glutamine, $1 \%$ solution of $1 \times$ ITS plus, $1 \%$ antibiotics solution (penicillin/streptomycin), $100 \mathrm{mg} / \mathrm{mL}$ sodium pyruvate, $50 \mu \mathrm{g} / \mathrm{mL}$ of 2-phosphate, L-ascorbic acid (AsAP), $40 \mu \mathrm{g} / \mathrm{mL}$ L-proline, $0.1 \mu \mathrm{M}$ dexamethasone and $10 \mathrm{ng} / \mathrm{mL}$ recombinant human TGF- $\beta_{1}$ (all supplements from Sigma, USA). Then cells were cultivated for 14 days, the medium was changed every 3 days. On the 14th day the cell granules were fixed in $10 \%$ formalin solution for $24 \mathrm{~h}$ and put into paraffin. To identify the sulfated proteoglycans the sections of granules were stained with toluidine blue [22-24].

Fibroblast differentiation of MSC-like cells was studied in 50\% of medium DMEM-HG (Sigma), with fibroblasts growth factor $2 \mu \mathrm{g} / \mathrm{mL}$ (Sigma) supplemented with 20\% inactivated FBS (HyClone, USA), 280 $\mathrm{mg} / \mathrm{L} \mathrm{L}$-glutamine, $50 \mathrm{mg} / \mathrm{L}$ gentamicin (all supplements from Sigma, USA). The cell concentration was $6 \times 10^{5}$ cells in $2 \mathrm{~mL}$. 18-days cultures were fixed and stained with the basic May-Grunwald stain [21].

Cloning of granulocyte-erythroid-macrophage-megakaryocyte colony forming units (CFU-GEMM): Cultures were performed in 24well plates (Costar, USA), $1 \times 10^{5}$ by nonadherent cells of bone marrow or blood /1 mL base culture medium based on Dulbecco's modified Eagle's medium (D-MEM, Sigma, USA) with 20\% FBS (HyClone, USA), erythropoietin $2 \mathrm{U} / \mathrm{mL}, 2 \mathrm{ng} / \mathrm{mL}$ interleukin-3, $0.2 \mathrm{ng} / \mathrm{mL}$ granulocytemacrophage colony stimulating factor, 10-5 M 2-mercaptoethanol (Thermo Scientific, USA), 1\% bovine serum albumin, $280 \mathrm{mg} / \mathrm{L}$ L-glutamine (all supplements from Sigma, USA), $50 \mathrm{mg} / \mathrm{L}$ gentamicin (Serva, Germany). Incubation is carried out at $37^{\circ} \mathrm{C}$ and $5 \% \mathrm{CO}_{2}$ atmosphere with absolute humidity, on the 7 th day $50 \%$ of supernatant was carefully removed, and the fresh base culture medium of the same volume was added. At the end of the 12th day of incubation the CFU-GEMM ( $>500$ cells per colony) was counted using an inverting microscope and morphological analysis of colonies was carried out [23]. Myeloid cell line is studied by peroxidase, monocyte-macrophage line - non-specific esterase. The cells of the erythroid line are identified by Wright's stain and subjected to benzidine dihydrochloride staining. The composition of CFU-GEMM consists of erythroid, granulocytic and monocytic cells.

Cloning of granulocyte colony forming units (CFU-G): Cultures were performed in 24-well plates (Costar, USA) with $2 \times 10^{5}$ nonadherent cells of bone marrow or blood $/ 1 \mathrm{~mL}$ of base culture medium based on RPMI-1640 (Sigma, USA) with 20\% FBS (HyClone, USA), $280 \mathrm{mg} / \mathrm{L}$ L-glutamine, antibiotics (Sigma, USA), $10^{-5} \mathrm{M}$ 2-mercaptoethanol (Thermo Scientific, USA), $4 \mathrm{ng} / \mathrm{mL}$ granulocyte colony stimulating factor and $0.9 \%$ methylcellulose solution (all supplements from Sigma, USA). Incubation is carried out at $37^{\circ} \mathrm{C}$ and $5 \% \mathrm{CO}_{2}$ atmosphere with an absolute humidity. On the 7th day CFU-G is counted using inverting microscope ( $>=50$ cells per colony), morphological analysis of colonies is carried out [21].

Cloning of the fibroblast colony forming units (CFU-F): Cultures were performed in 24-well plates at $1 \times 10^{5}$ by adherent cells of bone marrow, blood or lung/ $1 \mathrm{~mL}$ of the base culture medium based on the D-MEM with 10\% FBS (HyClone, USA), $280 \mathrm{mg} / \mathrm{L} \mathrm{L}$-glutamine, $50 \mathrm{mg} / \mathrm{L}$ gentamicin, $25 \mathrm{ng} / \mathrm{mL}$ fibroblast growth factor (FGF-basic), $30 \%$ methylcellulose solution (all supplements from Sigma, USA). Incubation is performed at $37^{\circ} \mathrm{C}$ and $5 \% \mathrm{CO}_{2}$ atmosphere with an absolute humidity for 10 days. At the end of the study CFU-F ( $>=50$ cells per colony) are counted using an inverting microscope and morphological analysis of colonies is carried out [25].

\section{ELISA assay}

Hydroxyproline and collagen type I measurements: Hydroxyproline and collagen type I were determined by ELISA according to manufacturer instructions (Cusabio Biotech CO., Ltd, China). The right lung lobes were excised and snap frozen after having measured the wet weight. Sensitivities were $>1.95 \mathrm{ng} / \mathrm{mL}$ for hydroxyproline and $>0.039 \mathrm{ng} / \mathrm{mL}$ for collagen type I.

Total soluble collagen assay: The right lung lobes homogenate supernatants were placed in $1.5 \mathrm{~mL}$ tubes. Sircol-dye was added, the content of the tubes homogenized for $30 \mathrm{~min}$ and centrifuged for $10 \mathrm{~min}(10,000 \mathrm{xg})$. The pellets were dissolved with alkaline reagent. Absorbance was read at $540 \mathrm{~nm}$. The total soluble collagen was 
Citation: Skurikhin EG, Pershina OV, Khmelevskaya ES, Ermakova NN, Reztsova AM, et al. (2014) Modulation of Stem and Progenitor Cells and Bleomycin-induced Pulmonary Fibrosis by Spiperone in Mice. J Stem Cell Res Ther 4: 210. doi:10.4172/2157-7633.1000210

Page 4 of 14

determined using a standard curve for the SircolTM assay (Biocolor Ltd, UK) according to manufacturer's instructions Results were expressed as mg collagen per right lung.

\section{Statistical analysis}

Data are expressed as mean \pm standard error of mean. Statistical variations were determined by analysis of variance (ANOVA) and Student's t-test. A P value less than 0.05 was considered statistically significant [26].

\section{Results}

\section{Morphological examination of the right lobe of the lung}

The Figure 1 shows the morphological picture of the right lobe of lung from $\mathrm{C} 57 \mathrm{BL} / 6$ mice of the control group ( $\mathrm{NaCl}$ injection), bleomycin control (bleomycin injection) and the experimental group (injection of bleomycin and spiperone) (dose, methods and schedule of reagents injection are presented in "Materials and Methods").

Staining of lung samples with hematoxylin and eosin revealed that on the third day after bleomycin administration spiperone treatment reduced the alveolar epithelial edema, exudation and infiltration of alveolar walls and lumen by inflammatory cells (neutrophils, lymphocytes, macrophages and plasma cells) compared to bleomycin control animals (Table 1) [27].

Spiperone reduced the degree of alveolocyte desquamation in alveolar lumen. As a result alveolar obliteration did not occur, alveolarcapillary membrane function remained and lung tissue destruction caused by bleomycin slowed down (Figure 1). Number of inflammatory cells in lungs was reduced (Table 1). Spiperone effect was observed in later periods of the experiment on the 7th, 14th, 21st days.

Staining of lungs with Van Giezon's picrofuchsin revealed that spiperone treatment reduced the amount of fibrotic masses in bleomycin mouse lung compared to untreated sick animals $(7,14,21$ day) (Figure 1 and Table 2). The maximum effect of compound was identified on the 21-day of the experiment.

\section{ELISA assay}

In terms of reducing the maximum amount of fibrotic lung mass by spiperone on the $21^{\text {st }}$ day of the experiment, enzyme immunoassay evaluated levels of type I collagen, hydroxyproline and total collagen in lung homogenates. It is shown that spiperone reduces the high levels of type I collagen (up 67.2\%), hydroxyproline (up 65.3\%) and total collagen (to $79.5 \%$ ) in animals with pulmonary fibrosis compared to untreated sick animals (Table 3).

These data showed that spiperone prevents the development of fibrosing alveolitis (pulmonary fibrosis) on the single dose intratracheal bleomycin model.

\section{Immunophenotypic characterization of mononuclear cells}

Hematopoietic stem cells and hematopoietic progenitor cells: "Long-term" HSCs ( $\mathrm{Lin}-\mathrm{Sca}-1^{+} \mathrm{c}-\mathrm{Kit}^{+} \mathrm{CD} 34$ ), «short-term" HSCs (Lin $\mathrm{Sca}-1^{+} \mathrm{C}-\mathrm{Kit}^{+} \mathrm{CD} 34^{+}$) and hematopoietic progenitor cells (Lin $-\mathrm{Sca}-1^{+} \mathrm{c}-$ $\mathrm{Kit}^{+}$) were studied in the bone marrow and lungs from intact mice, mice with bleomycin-induced pneumofibrosis, mice with bleomycininduced pneumofibrosis and treated with spiperone (Figure 2). On the 7 th day after intratracheal bleomycin injection there was a significant increase of $\mathrm{Lin}^{-\mathrm{Sca}}-1^{+} \mathrm{c}-\mathrm{Kit}^{+} \mathrm{CD} 34$ cells (up to $171 \%$ ), $\mathrm{Lin}^{-} \mathrm{Sca}-1^{+} \mathrm{C}$ $\mathrm{Kit}^{+} \mathrm{CD} 34^{+}$-cells (up to $333 \%$ ) and $\mathrm{Lin}-\mathrm{Sca}-1^{+} \mathrm{c}-\mathrm{Kit}^{+}$-cells (up to $204 \%$ ) in the lung compared to the control group (Table 4). At the same time the population of bone marrow "long-term" HSCs, "short-term" HSCs and progenitor cells decreased respectively by $10.3 \%, 71.8 \%$ and $13.1 \%$ compared to the control group.

Spiperone reduced the number of "long-term" HSCs (up to 80.8\%), "short-term" HSCs (up to 50\%) and progenitor hematopoietic cells (up to $71.1 \%$ ) in the lungs of mice treated with spiperone compared to the control sick animals. Meanwhile, in the bone marrow of mice treated with spiperone there was accumulation of immature hematopoietic cells in comparison to control animals with bleomycin-induced pneumofibrosis: $\mathrm{Lin}-\mathrm{Sca}-1^{+} \mathrm{c}-\mathrm{Kit}^{+} \mathrm{CD} 34$ cells to $122.8 \%$, Lin-Sca- $1^{+} \mathrm{C}-$ $\mathrm{Kit}^{+} \mathrm{CD} 34^{+}$cells to $215.6 \%$, $\mathrm{Lin}-\mathrm{Sca}-1^{+} \mathrm{c}-\mathrm{Kit}^{+}$- cells to $135 \%$.

Thus, in the treatment of pulmonary fibrosis by spiperone the reduction of HSCs and hematopoietic progenitor cells in lung and the increase of their number in bone marrow were observed.

CD45pos -cells: The Figure 3 shows the examination data of CD45pos-cells (pan-hematopoietic cells) in the lung and bone marrow on the 21 st day of the experiment. Spiperone significantly reduced the

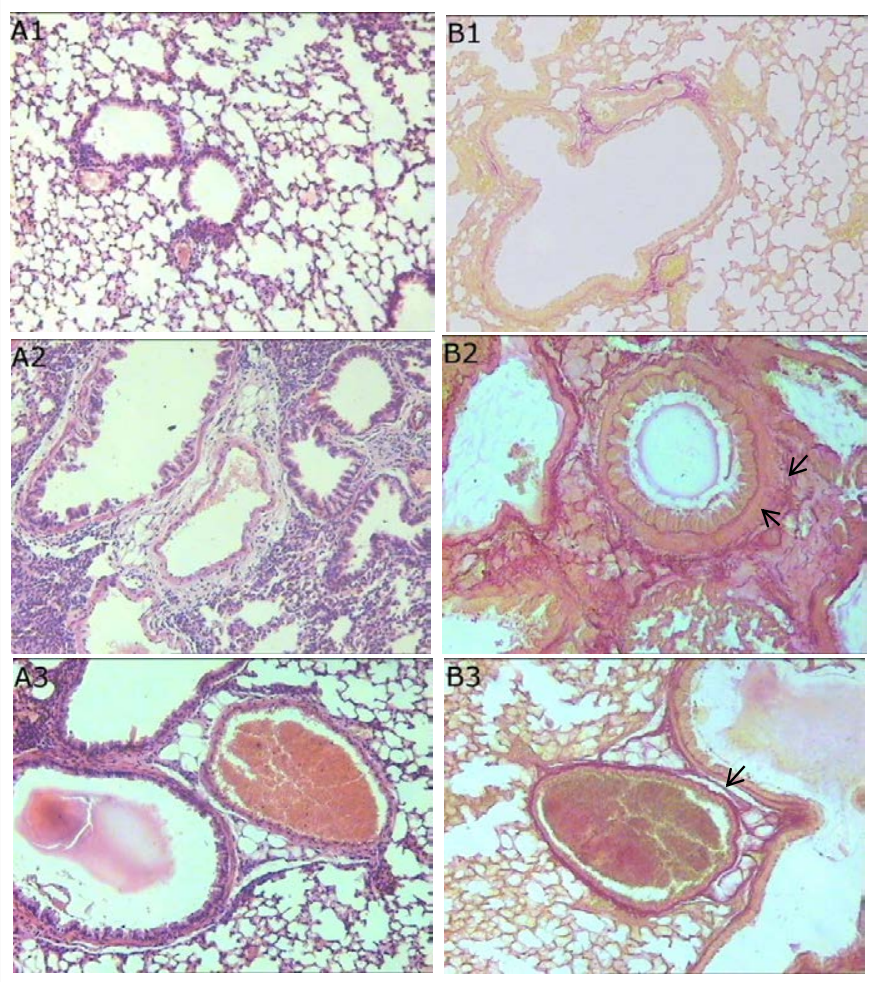

Figure 1: Photomicrographs of representative lung sections obtained from C57BL/6 mice. (A) Tissues were stained with haematoxylin and eosin in order to investigate inflammatory cells accumulation (7th day of the experiment); (B) tissues were stained with picrofuchsin to determine the collagen content (21st day of the experiment). (A1, B1) Mice receiving intratracheal $\mathrm{NaCl} 0.9 \%$, (A2, B2) Mice receiving intratracheal bleomycin, (A3, B3) Mice with fibrosis treated spiperone. A, pink-purple stains indicate cytoplasm, and blue the nuclei of inflammatory cells. A2, on the 7th day after bleomycin instillation it was observed the infiltration of alveolar and alveolar ducts interstitium by lymphocytes, macrophages, neutrophils, plasmocytes. A3, spiperone reduces the degree of alveocyte desquamation in alveolar lumen. $B$, dark pink stains are collagenous deposits. B2, the most expressed collagen fibers deposition after bleomycin injection was observed on the 21st day. B3, it is shown decrease in area of collagen deposition in spiperone-treated mice. The photomicrographs were taken using an Axio Lab.A1 (Carl Zeiss Microlmaging $\mathrm{GmbH}$; Göttingen, Germany) microscope and AxioCam ERc5s digital camera. All photomicrographs were at $100 \times$ magnification. 
Citation: Skurikhin EG, Pershina OV, Khmelevskaya ES, Ermakova NN, Reztsova AM, et al. (2014) Modulation of Stem and Progenitor Cells and Bleomycin-induced Pulmonary Fibrosis by Spiperone in Mice. J Stem Cell Res Ther 4: 210. doi:10.4172/2157-7633.1000210

Page 5 of 14

\begin{tabular}{|c|c|c|c|c|}
\hline Groups ( $n$ - number of mice in group) & Total mononuclear cells & Neutrophils & Macrophages & Lymphocytes \\
\hline Mice receiving IT $\mathrm{NaCl} 0.9 \%(n=10)$ & $271 \pm 24$ & $9 \pm 1$ & $16 \pm 2$ & $38 \pm 2$ \\
\hline \multicolumn{5}{|c|}{ 3rd day after bleomycin instillation } \\
\hline Mice with fibrosis $\mathrm{NaCl} 0.9 \%$ treated $(n=10)$ & $489 \pm 46$ * & $18 \pm 2$ & $29 \pm 2$ * & $81 \pm 8$ * \\
\hline Mice with fibrosis spiperone treated $(n=10)$ & $382 \pm 31$ * & $11 \pm 1 \&$ & $15 \pm 1 \&$ & $41 \pm 3 \&$ \\
\hline \multicolumn{5}{|c|}{ 7th day after bleomycin instillation } \\
\hline Mice with fibrosis $\mathrm{NaCl} 0.9 \%$ treated $(n=10)$ & $457 \pm 35$ * & $25 \pm 2$ * & $38 \pm 1$ * & $98 \pm 7$ * \\
\hline Mice with fibrosis spiperone treated $(n=10)$ & $324 \pm 29 \&$ & $12 \pm 1 \&$ & $13 \pm 1 \&$ & $42 \pm 4 \&$ \\
\hline \multicolumn{5}{|c|}{ 14th day after bleomycin instillation } \\
\hline Mice with fibrosis $\mathrm{NaCl} 0.9 \%$ treated $(n=10)$ & $642 \pm 59$ * & $20 \pm 2$ * & $32 \pm 2$ * & $82 \pm 9$ * \\
\hline Mice with fibrosis spiperone treated $(n=10)$ & $425 \pm 41 * \&$ & $11 \pm 1 \&$ & $14 \pm 1 \&$ & $45 \pm 4 \&$ \\
\hline
\end{tabular}

Lung tissues were obtained from C57BL/ 6 mice at the indicated time intervals after bleomycin treatment. The numbers of cell were counted per microscopic field at $\times 400$ magnification. Each value represents mean \pm SEM. Data represent mean of 2 independent experiments. ${ }^{*} \mathrm{P}<0.05$ - compared to the mice received intratracheal NaCl $0.9 \%$; $\& \mathrm{P}<0.05$ - compared to the mice received intratracheal bleomycin and $\mathrm{NaCl} 0.9 \%$ treated.

Table 1: The numbers of neutrophils, macrophages and lymphocytes in the lung parenchyma (per microscopic field) ( $\mathrm{M} \pm \mathrm{m})$.

\begin{tabular}{|c|c|c|c|}
\hline Day after bleomycin instillation & Mice received intratracheal NaCl $\mathbf{0 . 9} \%$ & $\begin{array}{c}\text { Mice with fibrosis NaCl } \mathbf{0 . 9 \%} \\
\text { treated }\end{array}$ & $\begin{array}{c}\text { Mice with fibrosis Spiperone } \\
\text { treated }\end{array}$ \\
\hline 7 & $1.12 \pm 0,05$ & $3.07 \pm 0.077^{*}$ \\
\hline 14 & $1.13 \pm 0,02$ & $3.91 \pm 0.077^{*}$ \\
\hline 21 & $1.15 \pm 0,07$ & $4.26 \pm 0.14$ * \\
\hline
\end{tabular}

The content of collagen fibers in lung was determined using a function for counting the area of the object in the image. Broncho-vascular strands were carefully removed from the analyzed areas. The relative fibrotic tissue area is calculated of by the formula:

$X=\sum a \times 100 /\left(S-\sum b\right)$

where: $\mathrm{a}$ - is the amount of pixels occupied by fibrotic tissue in 10 pictures of one drug, $\mathrm{S}$ - is the number of pixels corresponding to the total area of the image (using this camera and software $-4,423,680$ ), $b$ - a sum of pixels occupied by the empty part of the glass slide in 10 pictures of one drug.

Data represent mean of 3 independent experiments, $n=10 /$ group. Results are presented as mean and SEM. ${ }^{*} \mathrm{P}<0.05-\mathrm{compared}$ to the mice received intratracheal NaCl $0.9 \%$; \& $\mathrm{P}<0.05$ - compared to the mice received intratracheal bleomycin and $\mathrm{NaCl} 0.9 \%$ treated.

Table 2: The content of the connective tissue in the lungs of C57BL/6 mice ( $\%$ of the area of lung tissue).

\begin{tabular}{|c|c|c|c|}
\hline $\begin{array}{c}\text { Groups } \\
\text { (n - number of mice in group) }\end{array}$ & Collagen type I (ng/right lung lobe) & Hydroxyproline (ng/right lung lobe) & $\begin{array}{c}\text { Total soluble collagen ( } \mu \text { g/right } \\
\text { lung lobe) }\end{array}$ \\
\hline Mice received intratracheal $\mathrm{NaCl} 0.9 \%(n=10)$ & $121.1 \pm 11.7$ & $2915 \pm 240$ & $69.6 \pm 6.3$ \\
\hline Mice with fibrosis $\mathrm{NaCl} 0.9 \%$ treated $(n=10)$ & $233.3 \pm 22.4^{*}$ & $8714 \pm 651^{*}$ & $127.2 \pm 11.4^{*}$ \\
\hline Mice with fibrosis spiperone treated $(n=10)$ & $156.8 \pm 12.1 \&$ & $5693 \pm 298 \&$ & $101.2 \pm 6.1 \&$ \\
\hline
\end{tabular}

Hydroxyproline, collagen type I and total soluble collagen levels were measured in homogenate of right lung lobes from C57BL/6 mice ( $\mathrm{M} \pm \mathrm{m}$ ). Data represent mean of 2 independent experiments, Hydroxyproline and collagen type I were determined by ELISA according to manufacturer instructions (Cusabio Biotech CO., Ltd, China). The total soluble collagen was determined using a standard curve for the SircolTM assay (Biocolor Ltd, UK) according to manufacturer's instructions. Results were expressed as $\mu \mathrm{g}$ collagen per right lung. Data represent mean of 2 independent experiments. Results are presented as mean and SEM. ${ }^{*} \mathrm{P}<0.05-\mathrm{compared}$ to the mice received intratracheal $\mathrm{NaCl} 0.9 \%$; \& $\mathrm{P}<0.05$ - compared to the mice received intratracheal bleomycin and $\mathrm{NaCl} 0.9 \%$ treated.

Table 3: ELISA assay of hydroxyproline, collagen type I and total soluble collagen level on 21st day after bleomycin treatment.

number of pan-hematopoietic cells in lung of mice of experimental group relatively to bleomycin control. Bleomycin and spiperone had no effect on the level of CD45pos-cells in the bone marrow of mice.

These data showed that spiperone had selective inhibitory effect on the CD45 +-cells in the lungs of mice with pulmonary fibrosis.

CD45 neg-cells: On the 21st day of the experiment the population of CD45neg-cells in the lung of mice in the control group was $31.4 \%$ from all labeled mononuclear cells (Figure 3). Our results agree with the data of experimental study of K.S. Chow and colleagues (2006): the proportion of CD45 neg -cells in the lung of healthy mice is in the range from 30.0 to $40.0 \%$ of all labeled mononuclear cells. After bleomycin damage of alveolar epithelium it was observed the trend of indicator to decrease $(27.1 \%)$. After spiperone treatment the number of lung CD45neg-cells increased on $195.5 \%$ compared to bleomycin control.

Thus, during pulmonary fibrosis spiperone increases the number of CD45 neg-cells in lung and does not have an effect on CD45neg-cells of the bone marrow.

Mesenchymal stem cells: On the 21st day of the experiment the immunophenotype of CD45neg cells was studied in accordance with standard of MSCs in lung of C57BL/6 mice [28]. According to our data CD45neg lung and bone marrow cells in mice of all groups were expressed on the surface CD44, CD77, CD90, CD106 and were not expressed CD31 and CD34. Quantitative analysis showed that in the control group $1.7 \%$ of cells from all lung CD45 cells were defined as MSCs (Figure 4). In the fraction of lung CD45-cells of the bleomycin control mice the target subpopulation increased to $117.6 \%$ versus the control group. In the mice lung of the experimental group spiperone reduced the rate to the level of the control group (Figure 4).

In the bone marrow of control mice the number of cells with MSClike phenotype was $0.4 \%$ of all CD 45 neg cells. Meanwhile, bleomycin increased the concentration of bone marrow MSC-like cells up to $250 \%$ relative to the control group, spiperone had no effect on MSCs.

The presented data suggest that during pulmonary fibrosis spiperone reduces the population of MSC-like phenotype in the lung and has no effect on the bone marrow MSCs.

\section{Long-term cultures of adherent lung mononuclear cells}

The Figure 5 shows the dynamics of cell growth in secondary cultures of lung adheres mononuclear cells derived from the mice in 

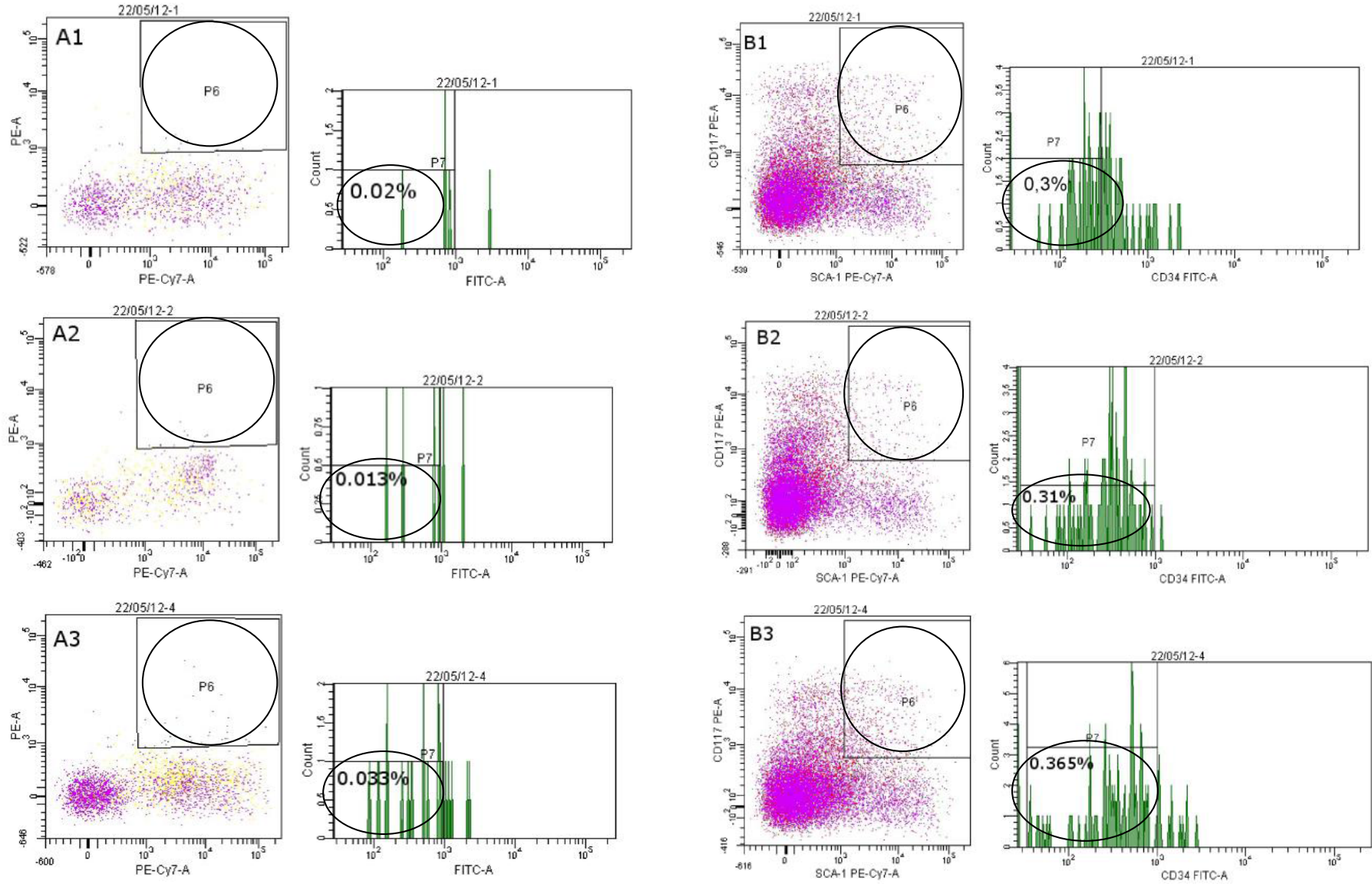

Figure 2: Characterization of hematopoietic stem cells isolated from C57BL/6 mice. The phenotype of cells from lung (A) and bone marrow (B) was studied on the protocol for hematopoietic stem cells (BD Biosciences). The HSC population taken through a Lin- selection (not shown), is shown gated Sca $1^{+}$and $\mathrm{c}-\mathrm{kit}^{+}$(P6), then displayed for CD34- (P7). The Lin-Sca1 ${ }^{+} \mathrm{C}-$-kit $^{+} \mathrm{CD} 34^{-}$cells are long-term (LT) HSC, and the Lin-Sca ${ }^{+} \mathrm{C}-\mathrm{kit}^{+} \mathrm{CD} 34^{+}$cells are considered short-term (ST) HSC (not shown). Thus, all two of these populations can be readily sorted from one sample. (A1, B1) HSCs isolated from mice after intratracheal administration of NaCl $0.9 \%$ (7th day of the experiment); (A2, B2) HSCs isolated from mice after intratracheal bleomycin administration (7th day of the experiment); (A3, B3) HSCs isolated from mice after intratracheal bleomycin administration and treated spiperone (7th day of the experiment). Dot plots are representative figures of three independent experiments with the mean from three independent experiments.

\begin{tabular}{|c|c|c|c|}
\hline Groups & $\begin{array}{c}\text { Lin-Sca-1 }{ }^{+} \text {c-kit+CD34- } \\
- \text { cells }\end{array}$ & $\begin{array}{c}\text { Lin-Sca-1+c-kit+CD34+ } \\
\text { - cells }\end{array}$ & $\begin{array}{l}{\text { Lin-Sca- } 1^{+} \text {c-kit }}^{+} \\
\text {- cells }\end{array}$ \\
\hline \multicolumn{4}{|c|}{ Lung } \\
\hline Mice received intratracheal $\mathrm{NaCl} 0.9 \%$ & $0.07 \pm 0.005$ & $0.018 \pm 0.001$ & $0.088 \pm 0.007$ \\
\hline Mice with fibrosis $\mathrm{NaCl} 0.9 \%$ treated & $0.12 \pm 0.01$ * & $0.06 \pm 0.005$ * & $0.18 \pm 0.01$ * \\
\hline Mice with fibrosis spiperone treated & $0.097 \pm 0.008$ * & $0.03 \pm 0.002 * \&$ & $0.128 \pm 0.011 * \&$ \\
\hline \multicolumn{4}{|c|}{ Bone marrow } \\
\hline Intact control & $0.39 \pm 0.03$ & $0.071 \pm 0.006$ & $0.46 \pm 0.04$ \\
\hline Mice with fibrosis $\mathrm{NaCl} 0.9 \%$ treated & $0.35 \pm 0.03$ & $0.051 \pm 0.005$ * & $0.4 \pm 0.03$ \\
\hline Mice with fibrosis spiperone treated & $0.43 \pm 0.04$ & $0.11 \pm 0.01 * \&$ & $0.54 \pm 0.05 \&$ \\
\hline
\end{tabular}

Membrane receptor's expression of murine HSCs from bone marrow or lung were assayed according to the protocol for BD Mouse Hematopoietic Stem and Progenitor Cell Isolation Kit (BD Biosciences, US). Data represent mean of 3 independent experiments. Results are presented as mean and SEM. ${ }^{*} \mathrm{P}<0.05-$ compared to the mice received intratracheal $\mathrm{NaCl} 0.9 \% ; \& \mathrm{P}<0.05$ - compared to the mice received intratracheal bleomycin and $\mathrm{NaCl} 0.9 \%$ treated.

Table 4: The content of HSCs and hematopoietic progenitor stem cells in the lung and bone marrow of C57BL/6 mice on the 7th day after bleomycin treatment ( $\pm \pm m$ ).

the control group bleomycin control and experimental group on the 21-st day of the experiment.

Morphological study of secondary cultures revealed mononuclear cells with mono and/or dual-core cells with morphological features of fibroblasts (long and thin, spindle-shaped form), endothelial cells (cobble form) and epithelial cells (cubic) (Figure 5.2). During the first 6-7 medium changes the main vial biomass increase was carried out by endothelial-like and epithelial-like cells. Starting with the $8^{\text {th }}$ medium change, the enrichment of culture with fibroblasts was observed and number of endothelial-like and epithelial-like cells decreased. By the end of the study (17-18 ${ }^{\text {th }}$ medium change) the cells with fibroblast morphology were primarily identified in the samples. The strongest increase in biomass was observed in the samples of the experimental group: cell cultures reached fusion $75.00 \%$ of the total area of the flask. 

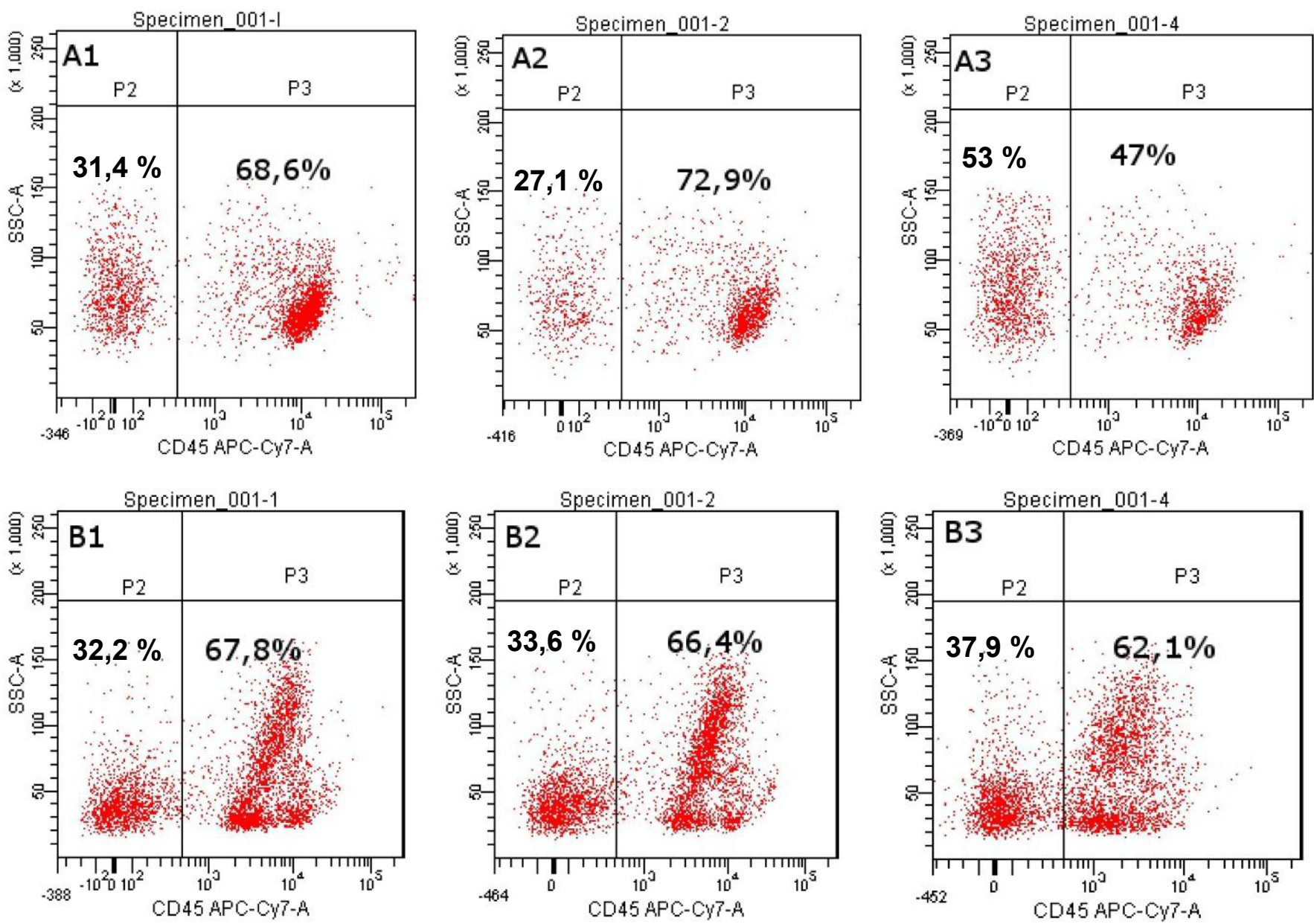

Figure 3: Analysis of murine pan-hematopoietic stem cells $\left(C D 45^{+}\right.$cells) and CD45 cells derived from lung (A) and bone marrow (B). Flow cytometry results cells from mice after intratracheal administration of $\mathrm{NaCl} 0.9 \%$ (A1, B1), mice after intratracheal administration of bleomycin (A2, B2), mice after intratracheal bleomycin administration and spiperone-treated (A3, B3) on 21 day of the experiment. Cells were analyzed by FACS with antibody to identify mouse CD45 APC-Cy7. The CD45 negative cell population and CD45 positive cell population is sorted from one sample. The number of CD45+ -cells in the mice lung of the control group was $68.6 \pm 4.9 \%$ of the labeled cells and control indicator of the bleomycin control animals did not significantly increase just to $72.9 \pm 5 \%$. Spiperone significantly reduced the number of pan-hematopoietic cells in mice lung with pulmonary fibrosis $(47.0 \pm 4.1 \%)$. Presented in the figure cytometric study results indicate that bleomycin and spiperone had no effect on the level of CD45+ -cells in the bone marrow. In the bone marrow the amount of CD45neg cells in mice of the control group was $32.2 \pm 3 \%$ of all labeled myelokaryocytes, bleomycin control mice $-33.6 \pm 5 \%$, in the experimental group - $37.9 \pm 3.5 \%$. Dot plots are representative figures of three independent experiments with the mean from three independent experiments.

The smallest increment of biomass was observed in cell cultures in the control group - $38.66 \%$. In cells samples of the experimental group the number did not exceed $54.42 \%$ (Figure 5.1).

After the end of the study, the cell surface markers in samples of the control and experimental groups were estimated. Up to $30.00 \%$ of CD45neg cells are MSCs $\left(\mathrm{CD} 44^{+} \mathrm{CD} 73^{+} \mathrm{CD} 90^{+} \mathrm{CD} 106^{+} \mathrm{CD} 31^{-} \mathrm{CD} 34\right)$.

Thus, spiperone has an inhibitory effect on the formation of monolayer in adhered cells cultures obtained from bleomycin injured mice lungs.

\section{Differentiation of lung MSCs into stromal lines cells}

It was studied differentiation into adipocytes, chondrocytes, osteocytes, and fibroblasts of the obtained mononuclear cells with the morphology of fibroblasts and MSC-like immune profile to confirm their multilinear differentiation potential $[21,29]$. The confirmation of multilineage differentiation of MSCs on the 21st day of the experiment is below.
Adipogenic differentiation: Grown in adipogenic medium with indomethacin and insulin MSC-like cells of control group and bleomycin control accumulated small lipid droplets. Lipid droplets fusion into large vacuoles was not observed. Valid differences in the number of cells with lipophilic inclusions in the samples from the control group and bleomycin control were not detected. Spiperone prevented the accumulation of lipid droplets in fibrotic lung cells (Figure 6).

Chondrogenic differentiation in three-dimensional granular cultures: Sedimentary (granular) culture formed from MSCs in chondrogenic medium with TGF- $\beta_{1}$. Histological research showed the presence of cartilage and bound matrix components in the samples of all studied sources. While staining the granules with toluidine blue the intense purple metachromasia was revealed, indicating a high content of sulfated proteoglycans. Toluidine blue staining indicated a high content of collagen fibers in the chondrogenic induced granular cultures (Figure 7). 
Citation: Skurikhin EG, Pershina OV, Khmelevskaya ES, Ermakova NN, Reztsova AM, et al. (2014) Modulation of Stem and Progenitor Cells and Bleomycin-induced Pulmonary Fibrosis by Spiperone in Mice. J Stem Cell Res Ther 4: 210. doi:10.4172/2157-7633.1000210
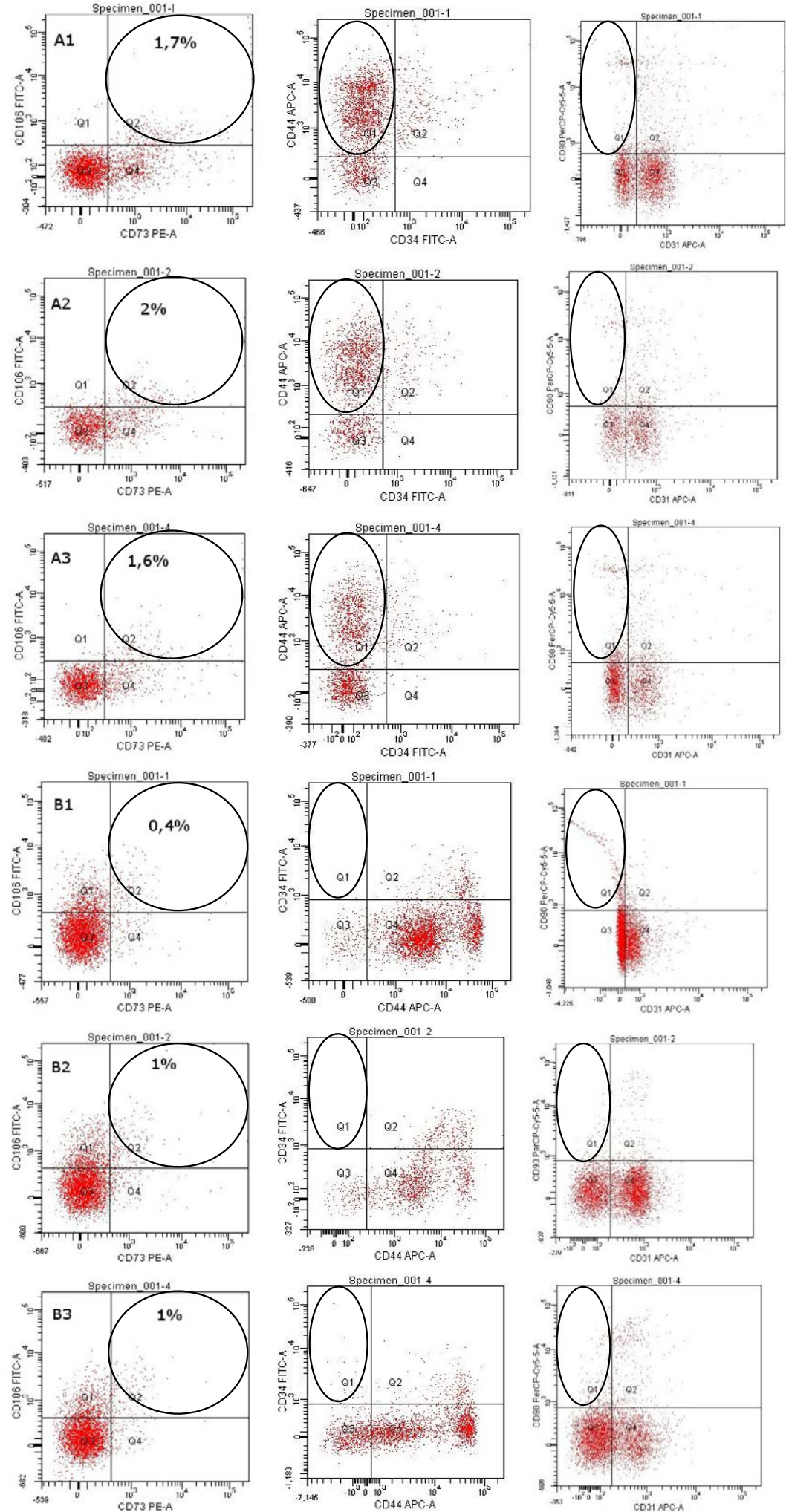

Figure 4: Assay of cell-surface antigens on murine mesenchymal stem cells from lung (A) and bone marrow (B). Lung-derived MSCs (A) and BM-derived MSCs (B) were labeled with antibodies against CD31, CD34, CD44, CD45, CD73, CD90, CD106 antigens and analyzed by flow cytometry. Flow cytometry results from mice after intratracheal administration of $\mathrm{NaCl} 0.9 \%(\mathrm{~A} 1, \mathrm{~B} 1)$, mice after intratracheal bleomycin administration (A2, B2), mice after intratracheal bleomycin administration and spiperone-treated $(A 3, B 3)$ on 21st day of the experiment. Our data imply that on the 21st day of the experiment lung and bone marrow CD45- cells of mentioned above groups mice expressed on the surface of CD44, CD77, CD90, CD106 and were negative for CD31 and CD34. The all of these populations is sorted from one sample. Dot plots are representative figures of three independent experiments with the mean percentage of at least three experiments. 
Citation: Skurikhin EG, Pershina OV, Khmelevskaya ES, Ermakova NN, Reztsova AM, et al. (2014) Modulation of Stem and Progenitor Cells and Bleomycin-induced Pulmonary Fibrosis by Spiperone in Mice. J Stem Cell Res Ther 4: 210. doi:10.4172/2157-7633.1000210

Page 9 of 14

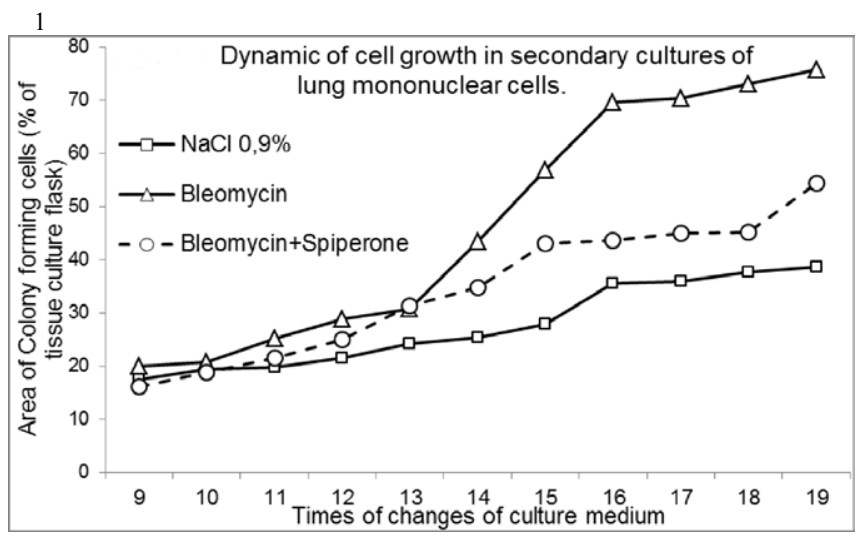

2
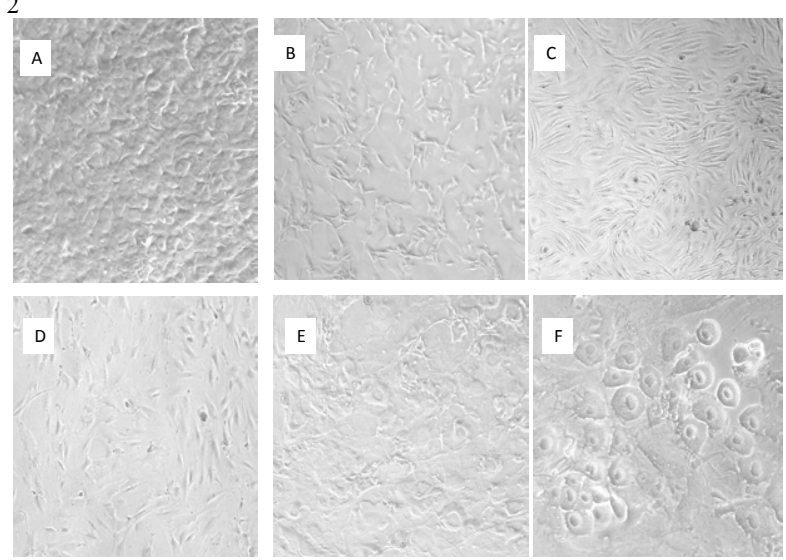

Figure 5: Dynamics of cell growth (1) and morphologic characteristics (2) in secondary cultures of lung adherent mononuclear cells derived from C57BL/6 mice. It is shown results of the control group, bleomycin control and experimental group (bleomycin+spiperone). 1, on the abscissa axis - times of changes of culture medium, on the ordinate - area of colony forming cells (\% of tissue culture flask). 2, reverse phase contrast images of cultured primary cells (PO). Endothelial-like (E, F) epithelial-like (A) cells and mononuclear and/ or binuclear cells with spindle-shaped fibroblast-like (B, C, D) morphology were identified in all primary cultures using morphological studies. Original magnification $\times 100$. The number of cells with the fibroblasts morphology was $5-10 \%$ of total vial cellularity. Starting from the 8 th cycle of changing medium it the culture enrichment by fibroblast-like cells and small-sized round cells was observed. The number of epithelial and endothelial like cells was progressively reduced. Round cells and predominantly fibroblastic morphology cells were detected in the samples at the end of research. Morphological studies are confirmed the analysis of immune profiles.

However, in samples of experimental group the cells in granules were congregated into a loose conglomerate with several structural components of the extracellular matrix.

Osteogenic differentiation: A characteristic feature of the osteogenic differentiation of mesenchymal stem cells in vitro is the formation of clusters. In our studies, MSC-like cells of control group in osteogenic medium with $\beta$-glycerophosphate formed separate clusters of cells growing in several layers. Positive cells staining according to von Kossa and Alizarin Red S confirmed the deposition of calcium and phosphate in the extracellular matrix. Calcium deposition area (S) was $136.13 \pm 24.03 \mathrm{~mm}^{2}$. MSC-like cells of bleomycin control have a lower capacity to form clusters in osteogenic medium with $\beta$-glycerophosphate compared to cells of control group ( $\mathrm{S}=29.32 \pm$ $\left.3.11 \mathrm{~mm}^{2} ;(\mathrm{n}=8, \mathrm{p}<0.001)\right)$. Several separate clusters formed instead of fusion cells culture (Figure 8).
Fibroblast differentiation: The cells showed a spindle-shaped morphology in all samples: a control group, bleomycin control, and experimental group. Staining by main May-Grunwald stain confirmed

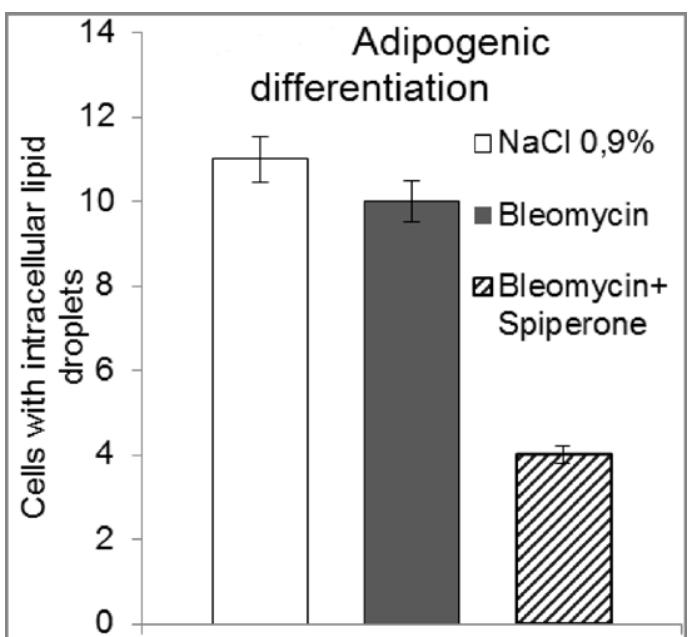

Figure 6: Multilineage differentiation of lung-derived MSCs. Adipogenic differentiation. The adipogenic differentiation was confirmed by the detection of small intracellular lipid droplets (oil red O staining). Yet, a final differentiation into mature adipocytes containing large, fused lipid vacuoles was not achieved. Results are presented as mean and SEM. On the ordinate axis - number of cells with intracellular lipid droplets, on the abscissa examined groups: mice with intratracheal administration of $\mathrm{NaCl} 0.9 \%$, mice with intratracheal administration of bleomycin, mice with intratracheal administration of bleomycin and spiperone-treated. Percentage of cells with lipophilic inclusions from the total cultured cells in the experimental group was $4.00 \pm 0.39 \%$, the samples of the control group $-11.00 \pm 2.32 \%(n=8, p$ $<0.001)$, in the samples of bleomycin control $-10.00 \pm 1.85 \%(n=8, p<0.001)$.

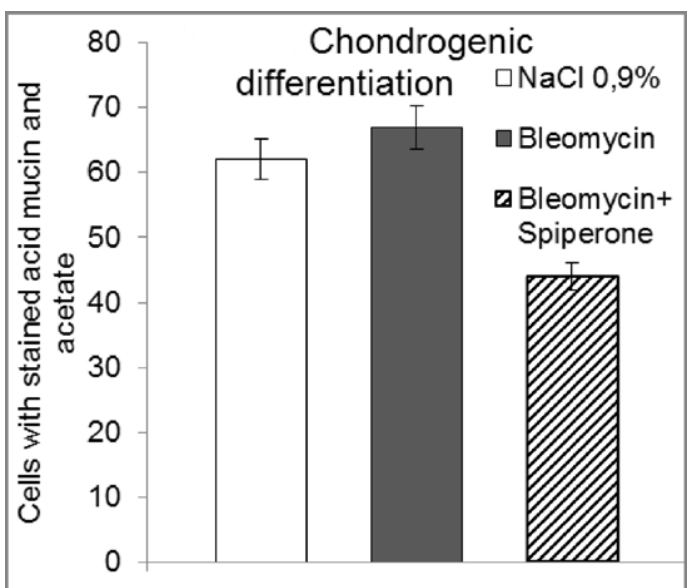

Figure 7: Multilineage differentiation of lung-derived MSCs. Chondrogenic differentiation. Chondrogenic differentiation was assessed histologically by demonstrating the presence of cartilage-related matrix components in the specimens. Chondrogenic-induced pellets from all assayed cell sources showed intense purple metachromasia in toluidine blue staining, indicating a high content of sulfated proteoglycans. Results are presented as mean and SEM. On the ordinate axis - number of cells with stained acid mucin and acetate, on the abscissa - examined groups: mice with intratracheal administration of $\mathrm{NaCl} 0.9 \%$, mice with intratracheal administration of bleomycin, mice with intratracheal administration of bleomycin and spiperonetreated. Percentage of cells stained with acetate and acidic mucins in histological samples of experimental group was lower $(44.00 \pm 3.34 \%)$, than in cells culture of control group $(62.00 \pm 7.21 \% ;(n=8, p<0.05))$ and in cells culture of bleomycin control $(67.00 \pm 7.82 \%$; $(n=8, p<0.05))$. 
the fibroblasts presence in all samples. In MSCs enriched culture of bleomycin control cells the amount of fibroblasts more than $29 \%$ ( $n=$ $8, \mathrm{p}<0.05)$ exceeds the control group. Spiperone reduced the number of fibroblasts in the samples of the experimental group to the level of the control group (Figure 9).

Thus, spiperone reduced the intensity of adipogenic, osteogenic, chondrogenic and fibroblast differentiation of MSC-like cells obtained during long-term culturing of adherent cells of mice lung with pulmonary fibrosis.

\section{Clonal activity of bone marrow, blood and lung cells}

Granulocyte-erythroid-macrophage-megakaryocyte colony forming units: Figure 10 shows the CFU-GEMM growth increase in liquid cultures of non-adherent myelokaryocytes (3rd, 21st day) and in blood (3rd, day 7th day) of bleomycin control mice relatively to the control group. Pulmonary fibrosis treatment by spiperone had a suppressive effect on CFU-GEMM formation in bone marrow samples (3rd, 7th, 14th, 21st day). Meanwhile, clonal activity of circulating in blood cells of experimental group exceeded it in bleomycin control ( 7 th day).

Thus, during pulmonary fibrosis spiperone has a suppressive effect on CFU-GEMM growth in bone marrow and blood samples.

Granulocyte colony-forming units: Intratracheal injection of bleomycin to mice initiated CFU-G growth in methylcellulose cultures of non-adherent bone marrow cells (3rd, 7th, 14th, 21st days) and blood (7th, 21st days) (Figure 11).

Spiperone reduced CFU-G outcome in the samples of bone marrow $(3,7,21$ days) and blood (3, 7, 14, 21-day) of experimental group.

From the presented data it follows that spiperone had an inhibitory effect on the CFU-G growth in cultures of bone marrow and blood cells obtained from mice with pulmonary fibrosis.

Fibroblast colony-forming units: In our research, a single

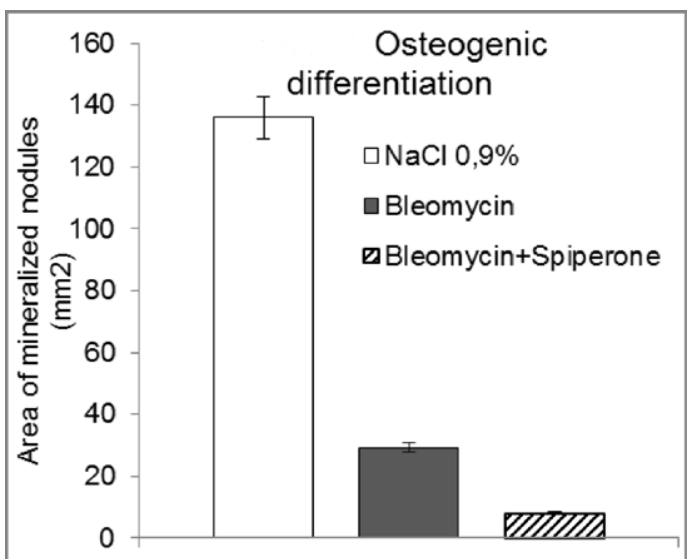

Figure 8: Multilineage differentiation of lung-derived MSCs. Osteogenic differentiation. During osteogenic differentiation cells altered their shape and assembled in clusters. The cluster formation is considered a typical feature of osteogenic MSC differentiation in vitro. Osteogenic differentiation was demonstrated by the presence of mineralized nodules stained black/ purple with von Kossa staining. $\beta$-glycerophosphate significantly increased formation of mineralized nodules. Results are presented as mean and SEM. On the ordinate axis - area of mineralized nodules $\left(\mathrm{mm}^{2}\right)$, on the abscissa examined groups: mice with intratracheal administration of $\mathrm{NaCl} 0.9 \%$, mice with intratracheal bleomycin administration, mice with intratracheal bleomycin administration and treated with spiperone.

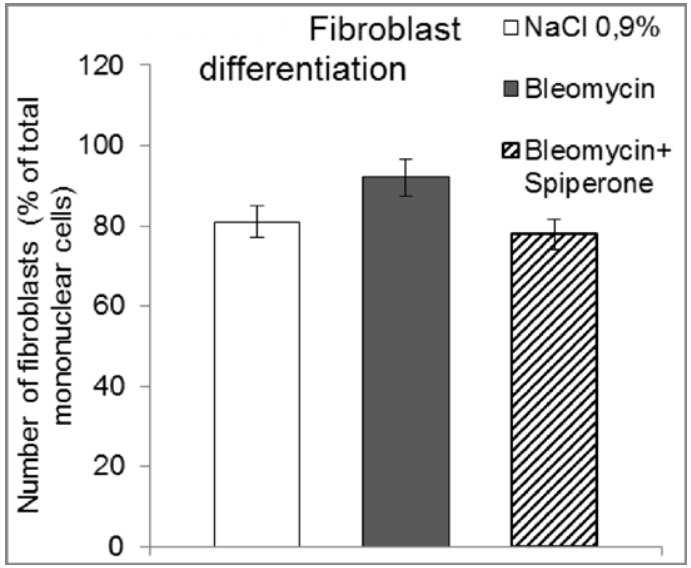

Figure 9: Multilineage differentiation of lung-derived MSCs. Fibroblast differentiation. The presence of fibroblasts in culture was confirmed by staining blue by May-Grunwald. All cultured cells had typical spindle-shaped fibroblast morphology and growth characteristics. Results are presented as mean and SEM. On the ordinate axis - number of fibroblasts (\% of total mononuclear cells), on the abscissa - examined groups: mice with intratracheal administration of $\mathrm{NaCl} 0.9 \%$, mice with intratracheal bleomycin administration, mice with intratracheal bleomycin administration and spiperone-treated.
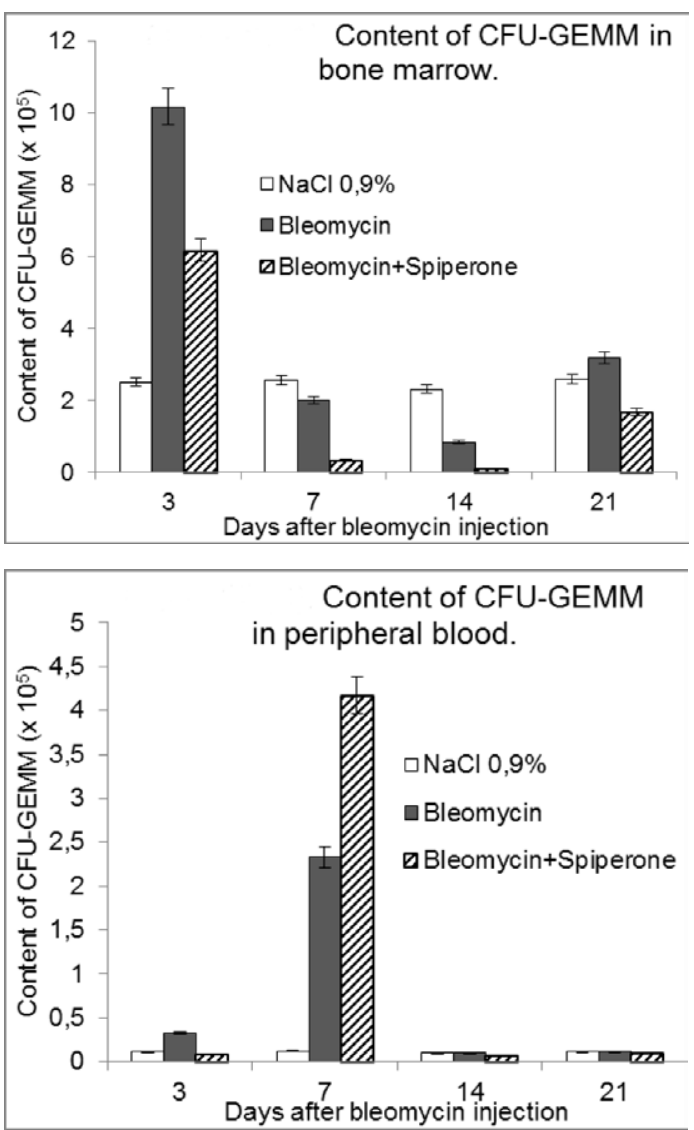

Figure 10: The effect of spiperone on content of CFU-GEMM in bone marrow and peripheral blood of C57BL/6 mice with pulmonary fibrosis. Mice received intratracheal $\mathrm{NaCl} 0.9 \%(\mathrm{NaCl} 0.9 \%)$, mice received intratracheal bleomycin (Bleomycin), and mice received spiperone after intratracheal bleomycin administration (Bleomycin + Spiperone). The number of colonies was showed on $Y$-line. CFU-GEMM was counted using inverted microscope $(>=500$ cells per colony), morphological analysis of colonies was carried out. Data represent mean colony counts \pm SEM. Assays were performed in duplicate. 

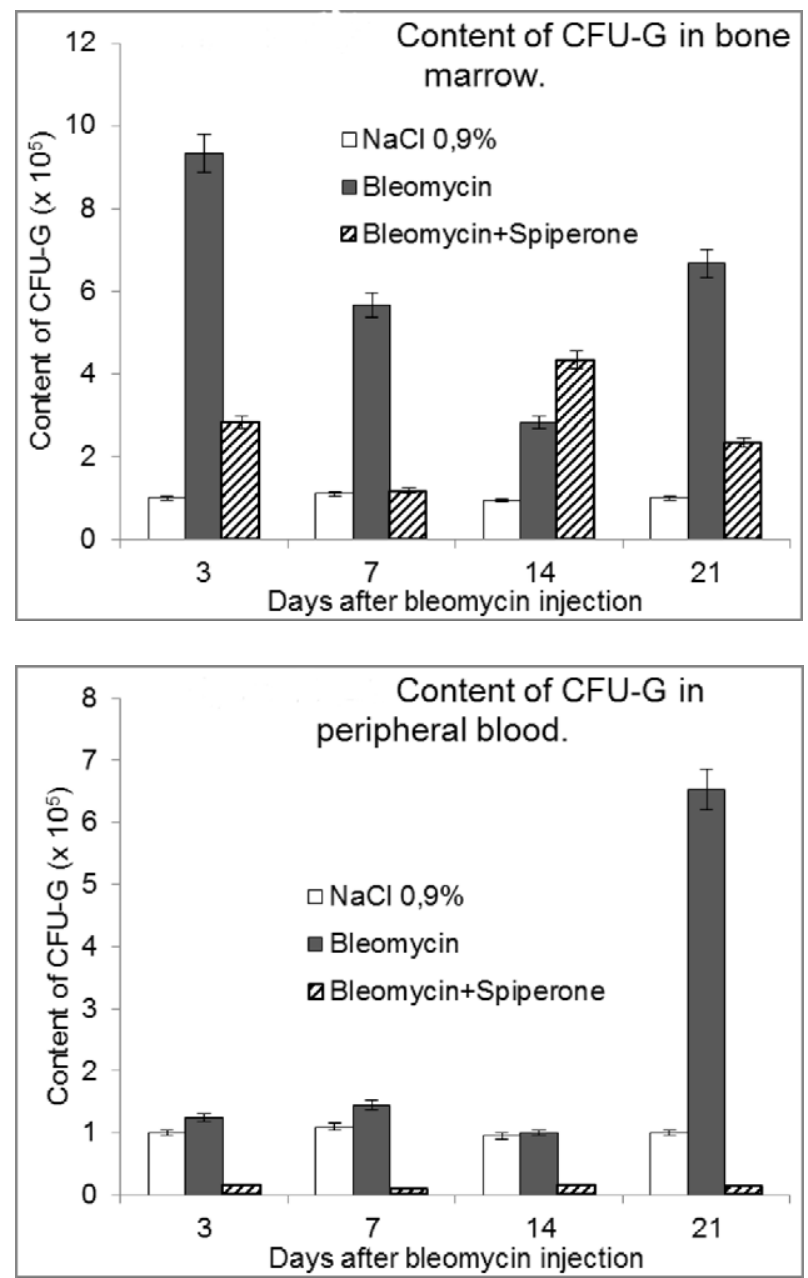

Figure 11: The effect of spiperone on content of CFU-G in bone marrow and peripheral blood of $\mathrm{C} 57 \mathrm{BL} / 6$ mice with pulmonary fibrosis. Mice received intratracheal $\mathrm{NaCl} 0.9 \%(\mathrm{NaCl} 0.9 \%)$, mice received intratracheal bleomycin (Bleomycin), and mice received spiperone after intratracheal bleomycin administration (Bleomycin + Spiperone). The number of colonies was showed on Y-line. CFU-G was counted using inverted microscope ( $>=50$ cells per colony), morphological analysis of colonies was carried out. Data represent mean colony counts \pm SEM. Assays were performed in duplicate.

intratracheal bleomycin installation induced generation of fibroblast colonies by adherent mononuclear cells of the study tissue (Figure 12). First of all, the stimulation of CFU-F growth was observed in samples of bone marrow cells (3rd, 7th, 14th, 21st day). CFU-F formation in blood cells samples was observed on the 7th, 21 st days, in the lung samples on the 7th, 14th, 21st days.

Spiperone had a suppressive effect on clonal activity of bone marrow (3rd, 21st day) and circulating in the blood (7th, 21st day) adherent cells of the experimental group. In the samples of experimental group lung CFU-F growth rate also decreased under the drug influence (7th, 14th day). An exception was the 21 st day of the experiment, when the number of colonies in the experimental group 5 times exceeds the number in the bleomycin control $(\mathrm{p}<0.001)$.

So, during pulmonary fibrosis spiperone reduces CFU-F growth in cultures of adherent cells in the bone marrow and blood. The inhibitory effect of the drug on lung adherent cells replaced by stimulating.

\section{Discussion}

The obtained results of morphological studies and ELISA allowed us to draw some conclusions. First, spiperone significantly reduces the intensity of the destructive processes in the lung from C57BL/6 mice under the conditions of bleomycin administration. Secondly, spiperone decreases infiltration alveoli and alveolar ducts interstitium by pan-hematopoietic cells (lymphocytes, macrophages, neutrophils, and plasmocytes) after bleomycin instillation. Third, spiperone decrease the levels of collagen type I, hydroxyproline and the amount of fibrotic masses in lung, confirming its antifibrotic effect (Figure 1, Tables 2 and 3 ).

HSCs are heterogeneous population [30]. "Long-term" CD34 HSCs and "short term" CD $34^{+}$-HSCs populations are found in bone marrow of recipients [31]. CD34- HSCs differentiate into CD34+ ${ }^{+}$HSCs that are capable to differentiating into all blood cell lines. In this study, we demonstrated significant increase the number of "long-term" HSCs (Lin-Sca- $\left.1^{+} \mathrm{c}-\mathrm{Kit}^{+} \mathrm{CD} 34\right)$ ), "short-term" HSCs $\left(\mathrm{Lin}-\mathrm{Sca}-1^{+} \mathrm{c}-\mathrm{Kit}^{+} \mathrm{CD} 34^{+}\right)$ and hematopoietic progenitor cells in the bleomycin-damaged lungs (7th day) (Figure 2). Number of hematopoietic progenitor cells and HSCs in the bone marrow decreased.

At the same time, intratracheal bleomycin administration increased the clonal activity of granulocyte-erythroid-macrophagemegakaryocyte colony forming units (CFU), and granulocyte CFU in the bone marrow and blood (Figures 10 and 11). This data suggest involvement of bone marrow "long-term" HSCs, "short-term" HSCs and hematopoietic progenitor cells in the development of bleomycin-induced lung inflammation and fibrosis. Probably, there is a mobilization "long-term" HSCs from bone marrow "niche» and their differentiation into "short-term" HSCs after bleomycin instillation. "Short-term" HSCs differentiate into neutrophils and macrophages. Earlier has been shown mobilization of hematopoietic progenitors from HSCs "niche" on model of bleomycin-induced pneumofibrosis [32]. These data indicate that bone marrow HSCs, hematopoietic progenitor cells and leucocytes migrate to the lungs and are involved in inflammation after bleomycin instillation.

Trabecular osteoblastes [33,34] and sinusoidal endothelium [35] represent the morpho-functional basis for "niche" in the bone marrow. Potential mechanisms of conservation HSCs in "niche" in a stationary condition: with the participation of N-cadherin (+) osteoblasts [34] and the interaction of the receptor tyrosine kinase Tie2 expressed on HSCs with its ligand angiopoietin-1 [36]. Exogenous stimuli can affect immune system cells which, through Toll-like receptors [37] or interferon- $\alpha$ [38] can induce proliferation and differentiation of HSC into mature hematopoietic cell lines [39]. Maybe mobilization from HSCs "niche" is initiated by immune cells after bleomycin instillation.

In this study, we demonstrated a significant increase in the number of HSCs in the bleomycin infected lung during spiperone treatment. Also, the fraction of bone marrow and circulating in blood $\mathrm{CD}_{4} 5^{+}$ cells population capable to form in vitro CFU-GEMM and CFU-G reduces. The explanation we see in the peripheral vascular effects of spiperone. Dopamine $\mathrm{D}_{2}$ receptors are present in lung [10,11]. It can be assumed that influencing the vascular tonus, spiperone indirectly helps the circulating in blood HSCs migration into the lung and, thereby, reduces circulating HSCs fraction. The inhibitory effect of spiperone on hematopoietic stem cells can be explained by the antagonistic action on the adrenergic receptors of "niches" osteoblasts. This hypothesis is based on the idea that sympathetic nerve fibers are one of elements of "niches" [19]. Osteoblasts express adrenergic receptors and are the direct effectors of sympathetic signals transmission [40]. 

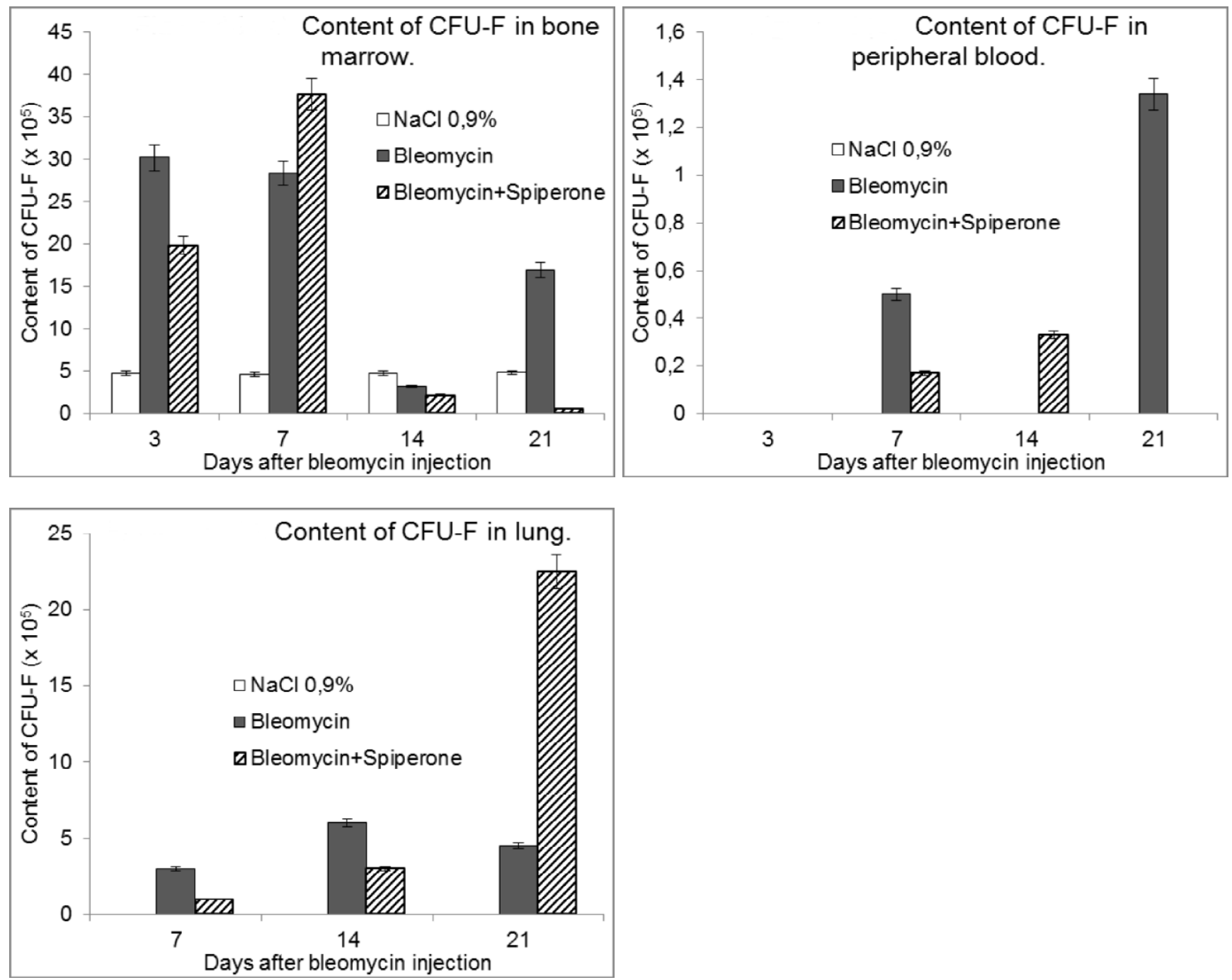

Figure 12: The content of CFU-F in culture bone marrow derived, peripheral blood derived and lung derived cells from C57BL/6 mice with pulmonary fibrosis. Mice received intratracheal $\mathrm{NaCl} 0.9 \%(\mathrm{NaCl} 0.9 \%$ ), mice received intratracheal bleomycin (Bleomycin), and mice received spiperone after intratracheal bleomycin administration (Bleomycin + Spiperone). The number of colonies was showed on Y-line. The CFU-F ( $>=50$ cells per colony) were counted using an inverted microscope and morphological analysis of colonies was carried out. Data represent mean colony counts \pm SEM. Assays were performed in duplicate.

Cells of mesenchymal origin participate in pathogenesis of pulmonary fibrosis $[41,42]$. We studied the spiperone effects on MSCs and progenitor fibroblast cells in the period of intensive collagen deposition in the lung. Spiperone significantly reduced the population of mesenchymal stem cells in the lung (21th day). Spiperone treatment of pulmonary fibrosis accompanied by a decrease of clonal activity of fibroblast progenitor cells (CFU-F) in bone marrow, lung and blood. The explanation we saw in the peripheral vascular effects of spiperone.

Another important aspect of the spiperone action on lung MSCs was related to their capacity for self-renewal and multilineage differentiation. Thus, the monolayer formation rate from cells with fibroblast morphology fell as a result of spiperone treatment. At the same time the amount of MSCs in a culture of newly formed CD45 cells was reduced compared with bleomycin control. Besides, spiperone inhibited lung MSCs differentiation in stromal lines cells (adipocytes, chondrocytes, osteoblasts, fibroblasts) (Figures 5-9).

In conclusion, it should be said that CD45--cells population contains not only MSCs and progenitor fibroblast cells. The absence of $\mathrm{CD} 45$ receptor characterizes bronchioles stem cells, which are defined as $\mathrm{CD} 45^{-\mathrm{CD}} 31^{-} \mathrm{CD} 34-\mathrm{Sca}-1^{\text {low }}$ and $\mathrm{AF}^{\text {low }}$ (Clara cells) [43]. The results of our flow cytometric research show that spiperone increases the amount of pulmonary $\mathrm{CD} 45 \mathrm{CD} 31^{-\mathrm{CD}} 34^{-}$- cells in diseased mice in the collagen deposition phase $(21$ st day) 1.95 times $(\mathrm{P}<0.05)$ compared with the control group (untreated fibrosis). Therefore we believe spiperone can involve Clara cells in the regeneration of alveolar epithelium at the fibrosis.

Thus spiperone as a selective antagonist of $\mathrm{D}_{2}$ dopamine receptors can effectively influence on the stem and progenitor cells in lung pathology. Additionally, spiperone blocks $5-\mathrm{HT}_{2 \mathrm{~A}} / 5-\mathrm{HT}_{1}$ serotonin receptors. In our opinion, anti-fibrotic effect of the drug in bleomycininduced fibrosis can be partially is connected with disturbance of serotonin mechanism fibroblast proliferation and collagen synthesis by fibroblasts both and levels of TGF- $\beta_{1}$, connective tissue growth factor and plasminogen activator inhibitor-1 is decreased in the lung [44]. Some authors attribute the synthesis of collagen fibers in the lung to 
Citation: Skurikhin EG, Pershina OV, Khmelevskaya ES, Ermakova NN, Reztsova AM, et al. (2014) Modulation of Stem and Progenitor Cells and Bleomycin-induced Pulmonary Fibrosis by Spiperone in Mice. J Stem Cell Res Ther 4: 210. doi:10.4172/2157-7633.1000210

Page 13 of 14

adrenergic receptors activity $[45,46]$. Due to the fact that spiperone is a1B-adrenoceptor antagonist, we do not exclude the realization of adrenergic mechanism.

\section{Conclusion}

In a bleomycin-induced pulmonary fibrosis spiperone prevents the development of alveolitis and fibrosis in the lungs of C57BL/6 mice. Spiperone violates migration of bone marrow "long-term" HSCs (Lin Sca- $\left.1^{+} \mathrm{c}-\mathrm{Kit}^{+} \mathrm{CD} 34^{-}\right)$, "short-term" HSCs (Lin-Sca- $1^{+} \mathrm{c}-\mathrm{Kit}^{+} \mathrm{CD} 34^{+}$) and hematopoietic progenitor cells into the lungs of bleomycin injured. Herewith the fraction of bone marrow and circulating hematopoietic progenitor cells capable of to form CFU-GEMM and CFU-G in culture is reduced. Spiperone disturbs migration of fibroblast progenitor cells capable of to form CFU-F in culture from bone marrow into the lungs. In addition, interrupt of dopamine mediation decreases the potential for self-renewal of lung MSCs and their activity of differentiation into stromal cell lines (adipocytes, osteoblasts, chondrocytes and fibroblast cells). These strategies may hold promise for developing novel treatment approaches for idiopathic pulmonary fibrosis.

\section{Competing Interests}

The authors declare no competing financial interests.

\section{References}

1. Tzilas V, Koti A, Papandrinopoulou D, Tsoukalas G (2009) Prognostic factors in idiopathic pulmonary fibrosis. Am J Med Sci 338(6): 481-485.[PubMed]

2. Mahendran S, Sethi $T$ (2012) Treatments in idiopathic pulmonary fibrosis: time for a more targeted approach? QJM 105(10): 929-934.[PubMed]

3. Khalil N, O'Connor R (2004) Idiopathic pulmonary fibrosis: current understanding of the pathogenesis and the status of treatment. CMAJ 171(2): 153-160.[PubMed]

4. Carbon M, Ghilardi MF, Feigin A, Fukuda M, Silvestri G, et al. (2003) Learning networks in health and Parkinson's disease: reproducibility and treatment effects. Hum Brain Mapp 19(3): 197-211.[PubMed]

5. Chesselet MF, Delfs JM (1996) Basal ganglia and movement disorders: an update. Trends Neurosci 19(10): 417-422.[PubMed]

6. Stoof JC, Kebabian JW (1984) Two dopamine receptors: biochemistry, physiology and pharmacology. Life Sci 35(23): 2281-2296.[PubMed]

7. Seeman P, Bzowej NH, Guan HC, Bergeron C, Reynolds GP, et al. (1987) Human brain D1 and D2 dopamine receptors in schizophrenia, Alzheimer's Parkinson's, and Huntington's diseases. Neuropsychopharmacology 1(1): 5-15.[PubMed]

8. Barrio JR, Satyamurthy $\mathrm{N}$, Huang $\mathrm{SC}$, Keen $\mathrm{RE}$, Nissenson $\mathrm{CH}$, et al. (1989) 3-(2'-[18F] fluoroethyl) spiperone: in vivo biochemical and kinetic characterization in rodents, nonhuman primates, and humans. J Cereb Blood Flow Metab 9(6): 830-839.[PubMed]

9. Amenta F, Ricci A, Tayebati SK, Zaccheo D (2002) The peripheral dopaminergic system: morphological analysis, functional and clinical applications. Ital J Anat Embryol 107(3): 145-167.[PubMed]

10. Bruzzone P, D'Andrea V, Motta C, Cavallotti C (2002) Occurrence of dopaminergic $(D(2))$ receptors within the rabbit pulmonary circulation. Pulm Pharmacol Ther 15(4): 393-398.[PubMed]

11. Kobayashi Y, Ricci A, Amenta F, Cavallotti C, Hattori K (1995) Localization of dopamine receptors in the rabbit lung vasculature. J Vasc Res 32(3): 200-206. [PubMed]

12. Goffinet AM, Leysen J, Labar D (1990) In vitro pharmacological profile of 3-N-(2fluoroethyl)spiperone. J Cereb Blood Flow Metab 10(1): 140-142.[PubMed]

13. Sharpe RJ, Arndt KA, Galli SJ, Meltzer PC, Razdan RK, et al. (1993) Topical application of spiperone or derivatives thereof for treatment of pathological conditions associated with immune responses. Patent № US 5244902A.

14. Sharpe RJ, Chandrasekar A, Arndt KA Wang ZS, Galli SJ (1992) Inhibition of cutaneous contact hypersensitivity in the mouse with systemic or topical spiperone: topical application of spiperone produces local immunosuppression without inducing systemic neuroleptic effects. J Invest Dermatol 99(5): 594600.[PubMed]

15. Skurikhin EG, Khmelevskaya ES, Pershina OV, Ermakova NN, Krupin VA (2013) Anti-fibrotic Effect of Reserpine on Lung Fibrosis: Stem Cells in the Pathogenesis of Pneumofibrosis. The Open Conference Proceedings Journal 4: 31-46.

16. Ortiz LA, Gambelli F, McBride C, Gaupp D, Baddoo M (2003) Mesenchymal stem cell engraftment in lung is enhanced in response to bleomycin exposure and ameliorates its fibrotic effects. Proc Natl Acad Sci USA 100(14): 84078411.[PubMed]

17. Prentø $P$ (1993) Van Gieson's picrofuchsin. The staining mechanisms for collagen and cytoplasm, and an examination of the dye diffusion rate model of differential staining. Histochemistry 99(2): 163-174.[PubMed]

18. Singh M, Chaudhary AK, Pandya S, Debnath S, Singh M (2010) Morphometric analysis in potentially malignant head and neck lesions: oral submucous fibrosis. Asian Pac J Cancer Prev 11(1): 257-260.[PubMed]

19. Katayama Y, Battista M, Kao WM, Hidalgo A, Peired AJ, et al. (2006) Signals from the sympathetic nervous system regulates hematopoietic stem cell egress from bone marrow. Cell 124(2): 407-421.[PubMed]

20. Mensing N, Gasse H., Hambruch N, Haeger JD, Pfarrer C, et al. (2011) Isolation and characterization of multipotent mesenchymal stromal cells from the gingiva and the periodontal ligament of the horse. BMC Vet Res 7: 1-13.[PubMed]

21. Skurikhin E, Pershina O, Dygai A (2013) Pathogenesis of pulmonary fibrosis and new approaches to the therapy. Neurotropic drugs modulate the activity of stem and progenitor cell. LAP LAMBERT Academic Publiching GmbH \& Co 45.

22. Luppa H (1980) Fundamentals of histochemistry 343.

23. Pierce E (1962) Histochemistry theoretical and applied. Foreign Literature 964

24. Selivanov EV (2003) Dyes in biology and medicine. ABC 43.

25. Goldberg ED, Dygai AM, Shahov VP (1992) Tissue culture methods in hematology. Tomsk 264.

26. Glantz S (1998) Biomedical Statistics: translation from English. Practice 459

27. Chow KS, Jun D, Helm KM, Wagner DH, Majka SM, et al. (2006) Isolation \& Characterization of Hoechstlow CD45negative Mouse Lung Mesenchymal Stem Cells. J Vis Exp 56: 3159.[PubMed]

28. Jun D, Garat C, West J, Thorn N, Chow K, et al. (2011) The Pathology of Bleomycin induced Fibrosis is associated with Loss of Resident Lung Mesenchymal Stem cells which Regulate Effector T-cell Proliferation. Stem Cells 29(4): 725-735.[PubMed]

29. Braun J, Hack A, Weis-Klemm M, Conrad S, Treml S, et al. (2010) Evaluation of the osteogenic and chondrogenic differentiation capacities of equine adipose tissue-derived mesenchymal stem cells. Am J Vet Res 71(10): 1228-1236. [PubMed]

30. Donnelly DS, Zelterman D, Sharkis S, Krause DS (1999) Functional activity of murine CD34+ and CD34- hematopoietic stem cell populations. Exp Hemato 27(5): 788-796.[PubMed]

31. Guo Y, Lübbert M, Engelhardt M (2003) CD34- Hematopoietic Stem Cells: Current Concepts and Cotroversies. Stem Cells 21(1):15-20.[PubMed]

32. Banerjee ER, Henderson WR (2012) Characterization of lung stem cell niches in a mouse model of bleomycin-induced fibrosis. Stem Cell Res Ther 3(3) 21.[PubMed]

33. Calvi LM, Adams GB, Weibrecht KW, Weber JM, Olson DP, et al. (2003) Osteoblastic cells regulate the haematopoietic stem cell niche. Nature 425(6360): 841-846.[PubMed]

34. Zhang J, Niu C, Ye L, Huang H, He X, et al. (2003) Identification of the haematopoietic stem cell niche and control of the niche size. Nature 425(6960): 836-841.[PubMed]

35. Kiel MJ, Yilmaz OH, Iwashita T, Terhorst C, Morrison SJ (2005) SLAM family receptors distinguish hematopoietic stem and progenitor cells and reveal endothelial niches for stem cells. Cell 121(7): 1109-1121.[PubMed]

36. Arai F, Hirao A, Ohmura M, Sato H, Matsuoka S, et al. (2004) Tie2/ angiopoietin-1 signaling regulates hematopoietic stem cell quiescence in the bone marrow niche. Cell 118(2): 149-161.[PubMed] 
Citation: Skurikhin EG, Pershina OV, Khmelevskaya ES, Ermakova NN, Reztsova AM, et al. (2014) Modulation of Stem and Progenitor Cells and Bleomycin-induced Pulmonary Fibrosis by Spiperone in Mice. J Stem Cell Res Ther 4: 210. doi:10.4172/2157-7633.1000210

Page 14 of 14

37. Nagai Y, Garrett KP, Ohta S, Bahrun U, Kouro T, et al. (2006) Toll-like receptors on hematopoietic progenitor cells stimulate innate immune system replenishment. Immunity 24(6): 801-812.[PubMed]

38. Essers MA, Offner S, Blanco-Bose WE, Waibler Z, Kalinke U, et al. (2009) IFNalpha activates dormant haematopoietic stem cells in vivo. Nature 458(7240): 904-908.[PubMed]

39. Frascoli M, Proietti M, Grassi F (2012) Phenotypic Analysis and Isolation of Murine Hematopoietic Stem Cells and Lineage-committed Progenitors. J Vis Exp 65: e3736.[PubMed]

40. Elefteriou F, Ahn JD, Takeda S, Starbuck M, Yang X, et al. (2005) Leptin regulation of bone resorption by the sympathetic nervous system and CART. Nature 434(7032): 514-520.[PubMed]

41. Bitencourt CS, Pereira PAT, Ramos SG, Sampaio SV, Arantes EC, et al. (2011) Hyaluronidase recruits mesenchymal-like cells to the lung and ameliorates fibrosis. Fibrogenesis Tissue Repair 4(1): 3.[PubMed]
42. Digay AM, Skurikhin EG, Pershina OV, Khmelevskaya ES, Ermakova NN et al. (2013) Stem and progenitor cells in the pneumofibrosis pathogenesis. Pathogenesis 11(1): 35-50

43. Teisanu RM, Lagasse E, Whitesides JF, Stripp BR (2009) Prospective isolation of bronchiolar stem cells based upon immunophenotypic and autofluorescence characteristics. Stem Cells 27(3): 612-622.[PubMed]

44. Fabre A, Marchal-Sommé J, Marchand-Adam S, Quesnel C, Borie R, et al (2008) Modulation of bleomycin-induced lung fibrosis by serotonin receptor antagonists in mice Eur. Respir J 32(2): 426-436.[PubMed]

45. Berg RA, Moss J, Baum BJ, Crystal RG (1981) Regulation of collagen production by the beta-adrenergic system. Journal of Clinical Investigation 67(5): 1457-1462.[PubMed]

46. Giri SN, Sanford DA Jr, Robison TW, Tyler NK (1987) Impairment in coupled beta-adrenergic receptor and adenylate cyclase system during bleomycininduced lung fibrosis in hamsters. Exp Lung Res 13(4): 401-416.[PubMed] 